\title{
Targeting TGF $\beta$ Signaling to Address Fibrosis Using Antisense Oligonucleotides
}

\author{
James T. March, Golnoush Golshirazi, Viktorija Cernisova, Heidi Carr, Yee Leong, \\ Ngoc Lu-Nguyen and Linda J. Popplewell * \\ Centre for Gene and Cell Therapy, School of Biological Sciences, Royal Holloway-University of London, \\ Egham, Surrey TW20 0EX, UK; James.March.2013@live.rhul.ac.uk (J.T.M.); \\ Golnoush.Golshirazi.2014@live.rhul.ac.uk (G.G.); Viktorija.Cernisova.2013@live.rhul.ac.uk (V.C.); \\ Heidi.Carr.2014@live.rhul.ac.uk (H.C.); Yee.Leong.2016@live.rhul.ac.uk (Y.L.); \\ Ngoc.Lu-Nguyen@rhul.ac.uk (N.L.-N.) \\ * Correspondence: Linda.Popplewell@rhul.ac.uk; Tel.: +44-178-444-3980
}

Received: 29 May 2018; Accepted: 14 June 2018; Published: 25 June 2018

\begin{abstract}
Fibrosis results from the excessive accumulation of extracellular matrix in chronically injured tissue. The fibrotic process is governed by crosstalk between many signaling pathways. The search for an effective treatment is further complicated by the fact that there is a degree of tissue-specificity in the pathways involved, although the process is not completely understood for all tissues. A plethora of drugs have shown promise in pre-clinical models, which is not always borne out translationally in clinical trial. With the recent approvals of two antisense oligonucleotides for the treatment of the genetic diseases Duchenne muscular dystrophy and spinal muscular atrophy, we explore here the potential of antisense oligonucleotides to knockdown the expression of pro-fibrotic proteins. We give an overview of the generalized fibrotic process, concentrating on key players and highlight where antisense oligonucleotides have been used effectively in cellular and animal models of different fibrotic conditions. Consideration is given to the advantages antisense oligonucleotides would have as an anti-fibrotic therapy alongside factors that would need to be addressed to improve efficacy. A prospective outlook for the development of antisense oligonucleotides to target fibrosis is outlined.
\end{abstract}

Keywords: fibrosis; transforming growth factor beta; antisense oligonucleotide

\section{Introduction}

When a tissue is injured acutely, the pathological response results in wound healing (reviewed in Kumar, 2018 [1]), as outlined in Figure 1a. Pro-inflammatory cytokines recruit immune cells to the site of injury to remove tissue debris which leads to transient inflammation. The inflammation response is acutely amplified by the release of chemokines, such as interleukin- 13 and interleukin-4, and the release of cytokines, such as transforming growth factor beta 1 (TGF $\beta 1$ ) and platelet-derived growth factor (PDGF), by the recruited immune cells themselves. This in turn leads to the temporary activation and proliferation of myofibroblasts to repair the insult. The resultant laying down of extracellular matrix (ECM) is transitory, with homeostasis between synthesis and degradation being re-established once the wound is healed through the proliferation of epithelial/endothelial cells. 

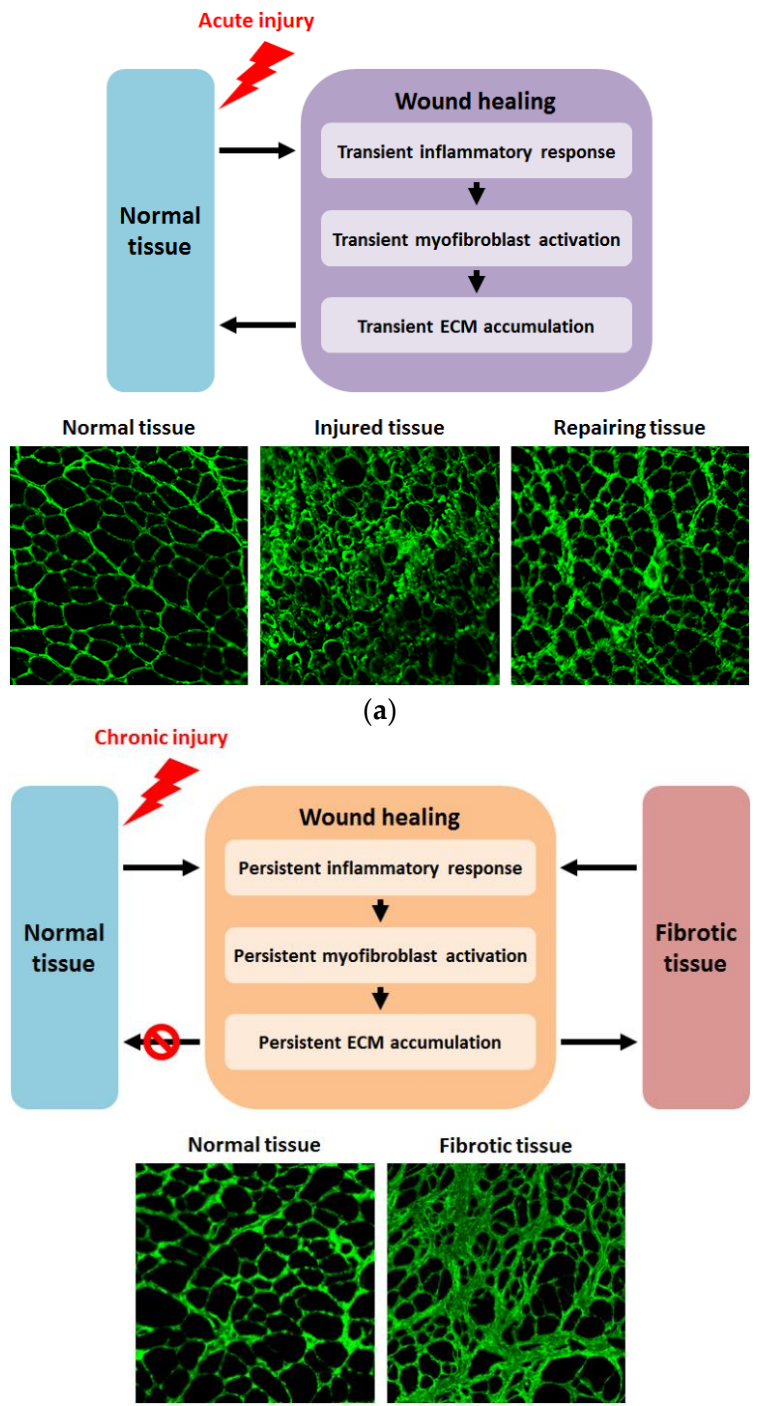

(b)

Figure 1. Outlines of normal wound healing following acute injury and fibrogenesis as a result of chronic injury: (a) Acute injury to normal tissue results in transient inflammation, leading to activation and proliferation of myofibroblasts, resulting in temporary ECM material accumulation, with restoration of ECM homeostasis once repair is complete and, ultimately, normalization of tissue architecture. Lower panels show cross-sections of normal (left), injured (center), and repairing (right) tibialis anterior muscle of 24-month-old wild-type mice immunostained for collagen VI at 200× magnification. Centre panel shows injured muscle 2 days after injury induced by injection with barium chloride, while right panel shows tissue repair 14 days post-injection, with muscle architecture beginning to normalize; (b) Chronic injury results in persistent inflammation, leading to recurrent myofibroblast activation and proliferation, which results in persistent and excessive ECM deposition and the development of fibrotic tissue. Lower panels show cross-sections at $200 \times$ magnification of the diaphragm of 9-month-old wild-type (left) and dystrophic $m d x$ (right) mice immunostained for collagen VI. Wild-type muscle shows normal tissue structure, while $m d x$ muscle displays fibrotic architecture with excessive and disruptive ECM deposition.

Tissue fibrosis is characterized by the excessive accumulation of ECM and can arise because of disease inducing chronic tissue injury, or alternatively because of abnormalities in any contributor of the normal wound healing process. In disease contexts, fibrosis contributes to the phenotype of the disorder, particularly in later stages (reviewed by Walgraven and Hinz 2018 [2]). Additionally, fibrosis 
can affect many different tissues, some more so than others, despite having some mechanisms in common [3-5]. Regardless of trigger, be it chronic injury due to disease or abnormal signaling, fibrosis develops due to unremitting activation of normal tissue repair mechanisms. Persistent inflammatory response leads to continued myofibroblast activation resulting in excessive ECM production and fibrotic remodeling of tissue architecture (reviewed by Murtha et al., 2017 [6]), as outlined in Figure 1b. Many therapeutics targeting multiple components of the fibrotic pathway are at various stages of development (reviewed by Li et al., 2017 [7]). One approach that has shown much preclinical promise is the use of antisense oligonucleotides (AOs) to suppress expression of pro-fibrotic factors. Several beneficial features of AOs make this strategy attractive, such as their non-immunogenicity, the transience of target knockdown, the potential for flexibility in dosage, as well as the recent approval of two antisense oligonucleotide drugs for the treatment of genetic disease [8]. On this basis, this review will focus on the use of AOs as anti-fibrotic agents.

\section{Transforming Growth Factor $\beta$ Signaling in Fibrosis}

The TGF $\beta$ superfamily of cytokines includes three TGF $\beta$ isoforms (TGF $\beta 1-3$ ), activins, inhibins, bone morphogenetic proteins (BMPs), growth and differentiation factors (GDFs) such as myostatin (also known as GDF8), and anti-mullerian hormone (AMH) $[9,10]$. TGF $\beta 1$, the prototypical member of this superfamily, is viewed as a critical molecular factor that drives the formation of fibrosis accompanying many disease states [11,12]. Indeed, TGF $\beta 1$ is persistently overexpressed in many fibrotic disorders and is strongly implicated as a principal driver of pathological fibrotic remodeling of different organs, including the lung [13,14], liver [15,16], kidney [17], heart [18,19], and muscle [20-22].

Another relatively well-characterized member of the TGF $\beta$ superfamily is myostatin. Myostatin is produced exclusively in skeletal muscles and acts mainly as a negative regulator of muscle development. Mutation of myostatin in humans and multiple animal species results in a hypermuscular and low body fat phenotype [23-26]. Therefore, modulating myostatin signaling has become an attractive approach to treat muscle wasting associated with muscular dystrophy, cancer cachexia, sarcopenia, trauma and diabetes [27-32]. Interestingly, while studying the effect of myostatin knockdown on muscle mass and strength, many groups have observed a corresponding reduction of fibrosis. For instance, in the $m d x$ mouse model of Duchenne muscular dystrophy (DMD) combined with myostatin knockout, Wagner et al., 2002 identified that the diaphragm muscle of these animals had significantly less fibrosis compared with $m d x / m s t n^{+}$littermates [33]. Furthermore, other groups confirmed fibrosis reduction in mice treated with anti-myostatin neutralizing antibodies and peptides [27,34]. Researchers at The Johns Hopkins University were the first group to identify that myostatin could not only negatively regulate the growth of myocytes, but also directly regulate skeletal muscle fibrosis [35]. However, while some evidence indicates that myostatin stimulates the formation of cardiac fibrosis, it is not currently known what role myostatin might play in the formation of fibrosis in other organs, such as liver, kidney, and lung [10].

Both TGF $\beta 1$ and myostatin are synthesized in precursor forms consisting of a signal peptide, an N-terminal latency associated peptide (LAP) and a C-terminal domain that forms the active ligand [12]. Sequential proteolytic cleavages in the endoplasmic reticulum remove initially the signal peptide, and then release the LAP, which then binds to homodimers of mature ligand and keeps them in a latent propeptide complex that cannot interact with their receptors [12,36,37]. Additionally, in the case of TGF $\beta 1$, the LAP facilitates binding of the latent propeptide complex to the latent TGF $\beta$ binding protein (LTBP), which further keeps TGF $\beta 1$ in an inactive state [12,38]. Such latent propeptide complexes can be cleaved in the ECM by proteases such as matrix metalloprotease (MMP) 2 and MMP9 (in the case of TGF 31 ) [12,39] or BMP1/tolloid-like metalloproteases (in the case of myostatin) [40] to release active ligand, which can subsequently bind to cognate receptors.

Although members of the TGF $\beta$ superfamily can signal through several pathways, the canonical pathway (outlined for TGF $\beta 1$ in Figure 2) involves the formation of a complex of activated ligand with a cognate tetrameric receptor, consisting of two type I (also known as activin-like kinase or 
ALK receptors) and two type II subunits with serine/threonine kinase activity [9,10,41]. A total of seven type I and five type II receptors have been identified, all forming complexes with different members of the TGF $\beta$ superfamily [10]. For example, TGF $\beta 1$ forms complexes with the type I receptor ALK5 and the type II receptor TGF $\beta$ receptor II (TGF $\beta$ RII), while myostatin binds to ALK4 or ALK5 and the type II receptor activin receptor type IIB (ActRIIB) $[9,10,41]$. Upon ligand binding, the two types of receptor kinases act sequentially, with initial binding to the type II receptor inducing the recruitment and phosphorylation of type I receptors [9,10,41]. Upon phosphorylation, the type I receptors become active and phosphorylate receptor-activated Smad proteins, which in the case of TGF $\beta 1$ and myostatin are Smads 2 and 3 [9,10,41,42]. Upon phosphorylation, Smad2/3 forms heteromeric complexes with Smad4, which then translocate to the nucleus and facilitate activation of expression of target genes $[9,41]$.

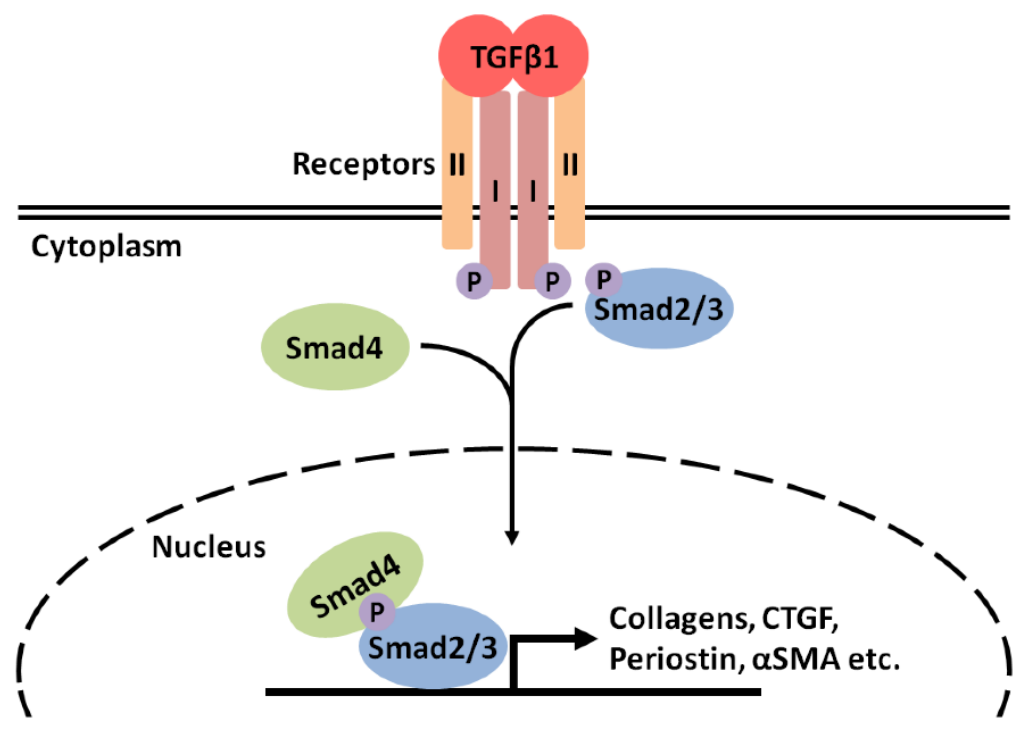

Figure 2. Outline of the canonical TGF $\beta 1$ signaling pathway. Upon activation, TGF $\beta 1$ binds to its cognate receptor, which consists of two type I (ALK5) and two type II (TGF $\beta$ RII) subunits. Initial ligand binding is to TGF $\beta$ RII induces the recruitment of ALK5. TGF $\beta$ RII subunits phosphorylate ALK5 subunits initiating their activation. ALK5 subunits then phosphorylate the receptor-activated Smad proteins Smads 2 and 3. Phosphorylated Smad2/3 complex with Smad4 and then translocate to the nucleus to facilitate induction of expression of target genes, including profibrotic genes such as those for collagens, CTGF, periostin and $\alpha \mathrm{SMA}$. Canonical myostatin signaling proceeds in an analogous manner, but with different cognate receptors.

Many target genes induced by TGF $\beta 1$ via this signaling pathway are downstream pro-fibrotic genes, such as those encoding the ECM components fibronectin and different collagens $[11,14,18,43-46]$, proteoglycans [47,48], plasminogen activator inhibitor-1 (PAI1) [49,50], integrins [51], connective tissue growth factor (CTGF) [52-56], periostin [57,58], tissue inhibitor of metalloproteases (TIMPs) [45], and $\alpha$-smooth muscle actin ( $\alpha$ SMA) $[46,59,60]$. Overall, the stimulation of pro-fibrotic genes by TGF $\beta 1$ promotes the differentiation of quiescent fibroblastic cell types to a pro-fibrotic, $\alpha$ SMA-positive, collagen-secreting, myofibroblastic phenotype in liver [46], lung [14], kidney [60], heart [18], and muscle [61]. Ultimately, this results in the fibrogenesis seen in many pathological conditions. Likewise, myostatin also stimulates expression of pro-fibrotic genes in this manner [10]. A pro-fibrotic environment in dystrophic skeletal muscle also appears to be promoted by myostatin through the induction of muscle fibroblast proliferation, as well as through the inhibition of fibroblast apoptosis [62]. The resulting increase in fibroblast number stimulates ECM accumulation and fibrotic alterations to muscle architecture [62]. 
Additionally, certain factors appear to modulate TGF $\beta$ signaling. For instance, it has been suggested that connexin 43 contributes to the TGF $\beta 1$-mediated induction of $\alpha$ SMA transcriptional activity [63]. Connexin isoforms, such as connexin43, oligomerize to form connexins, hemichannels comprised of six connexin subunits, which in turn dimerize to form gap junctions, transmembrane intercellular channels that allow direct signaling between cells and the exchange of small $(<1 \mathrm{kDa})$ metabolites and ions $[64,65]$. Connexin 43 has been extensively studied and is found in many tissues including eyes, oral tissue, skin, and heart, and evidently contributes to the fibrosis seen in these tissues [63,66-68]. In part, this contribution of connexin 43 to fibrogenesis appears to proceed via the TGF $\beta 1$-mediated activation of fibroblasts to myofibroblasts via $\alpha$ SMA induction $[63,68]$. Connexin 43 may contribute to this induction of $\alpha$ SMA by the release of Smad2/3 from anchors on microtubules via competitive binding to microtubule anchor-points [69]. This would lead to increased availability of Smad2/3 for phosphorylation by the TGF $\beta 1$ receptor complex and thus increased activation of target genes, such as $\alpha \mathrm{SMA}[69]$.

Some micro RNAs (miRs) also seem to exert regulatory effects on TGF $\beta$ signaling, and in so doing act as both suppressors and inducers of fibrogenesis. For example, studies have indicated that miR-29 functions as a negative regulator of TGF $\beta$ induced fibrosis, while also being downregulated itself through TGF $\beta$ signaling mechanisms in certain fibrotic contexts [70-74]. However, other miRs, such as miR-21 and miR-192, act to promote fibrosis through induction of TGF $\beta 1$ expression [75], or through inhibition of negative regulation of TGF $\beta 1$ signaling to amplify the pro-fibrotic signal $[76,77]$.

\section{The Use of AOs to Target TGF $\beta$ Signaling to Inhibit Fibrosis}

On account of the evident critical role of TGF $\beta$ signaling in fibrosis, TGF $\beta 1$ and myostatin represent potential targets for functional antagonism or downregulation of expression, to prevent proliferation of pathological fibrotic tissue. TGF $\beta 1$ has been targeted with neutralizing anti-TGF $\beta 1$ monoclonal antibodies [78-80], TGF $\beta 1$-targeting inhibitor peptides [81], and soluble TGF $\beta$ RII as a TGF 31 -ligand trap [82]; while myostatin has also been targeted with neutralizing anti-myostatin antibodies [27,83], myostatin propeptides [34,84], myostatin antagonists [85-87], and soluble myostatin receptors [88]. In addition to targeting these factors themselves, strategies have been utilized to suppress TGF $\beta$ signaling via targeting the cognate receptor complexes or SMAD2/3 for the inhibition of fibrogenesis. For example, small molecule inhibitors have been used to repress the function of TGF $\beta R I / A L K 5$ and TGF $\beta$ RII [89-91]. Besides these strategies, AOs themselves have been utilized to target TGF $\beta$ signaling at multiple points, including components of the TGF $\beta$ signaling cascade, such as ALK5 and SMAD3, and modulators of TGF $\beta$ signaling, such as connexin 43 and miRs, for the amelioration of pathological fibrogenesis.

\subsection{TGF $\beta 1$}

In the case of TGF $\beta 1$ itself, AOs have been utilized to repress expression in several fibrotic models. For example, in vivo treatment with AOs targeting the translation initiation region of the TGF $\beta 1$ mRNA resulted in reduced TGF $\beta 1$ expression and suppression of ECM expansion in the anti-Thy 1.1 antibody model of glomerulonephritis and the unilateral ureteral obstruction (UUO) model of tubulointerstitial fibrosis [92,93]. Likewise, treatment with similar TGF $\beta 1$-targeting AOs reduced expression of TGF $\beta 1$ and the fibrotic ECM components fibronectin and collagen IV in in vitro and in vivo mouse models of diabetic renal hypertrophy [94]. AOs targeting TGF $\beta 1$ have also been utilized to preclude scarring during flexor tendon repair in mice [95]. These AOs inhibited TGF $\beta 1$ expression, reduced collagen III expression, and improved tendon repair by reducing the formation of fibrous adhesions between the tendons and the synovial sheath [95]. An alternative approach has utilized viral delivery of an antisense-RNA complementary to the $3^{\prime}$ coding sequence of the TGF $\beta 1 \mathrm{mRNA}$ to reduce TGF $\beta 1$ expression, signaling, and target gene expression, such as expression of $\alpha \mathrm{SMA}$ and collagen I, by activated hepatic stellate cells [96]. 


\subsection{Myostatin}

AOs have been utilized to disrupt the myostatin pre-mRNA by inducing disruptive exon skipping to suppress myostatin expression. The efficacy of utilizing AOs for myostatin knockdown has been demonstrated in $m d x$ mice [97-99]. Of note, we and others experienced that antisense treatment was significantly more effective when the AOs were administered locally into the muscle [97], rather than systemically by intraperitoneal or intravenous delivery $[98,99]$. Insufficient uptake into target tissues, high accumulation in the liver, and rapid clearance via the kidney are potential reasons for this limitation [100]. In particular, skeletal muscle-derived myostatin undergoes complex post-translational modification to maintain the balance of mature/precursor protein in the blood. Once the balance is disrupted, i.e., by exogenous compounds, precursor myostatin in its latent form can be activated to regain the balance, diminishing the therapeutic benefit [101]. These obviously are major drawbacks in the antisense approach for myostatin knockdown, compared to other strategies suppressing myostatin at protein level, and should be considered in any experimental plan. However, such problems can be overcome by using higher $\mathrm{AO}$ doses, or more frequently repeated $\mathrm{AO}$ delivery; feasible approaches given that AOs can be manufactured in large scale in a standardized manner.

\subsection{ALK5}

The ALK5 receptor (TGF $\beta$ RI) has been targeted with AOs for the inhibition of fibrosis ex vivo in cultures of Dupuytren's patient tissue [91], and in the $m d x$ mouse model of DMD [102]. In ex vivo Dupuytren's cultures, ALK5-targeting AOs appeared to suppress aspects of the fibrotic phenotype through the suppression of TGF $\beta 1$ signaling [91]. Likewise, in multiple cell lines ALK5-targeting AOs also inhibited TGF $\beta 1$ signaling, while in $m d x$ mice these AOs decreased the expression of pro-fibrotic collagen III, CTGF and PAI1 [102]. However, ALK5-targeting AOs did not reduce the extent of fibrosis in the mice compared to controls, an effect that may, as Kemaladewi et al., 2014 point out, be due to the relatively young age of the mice or the very limited length of treatment utilized in the study [103].

\subsection{Smad3}

AOs have also been used to target Smad3 for the suppression of TGF $\beta 1$ signaling. Expression of Smad3 appeared to be blocked following AO treatment in keloid fibroblasts, an effect which was accompanied by suppression of collagen I expression [104]. Additionally, targeting Smad3 with AOs ameliorated flexor tendon scarring and improved healing after injury and surgical repair in mice [95]. A further study utilized a dual function synthetic oligodeoxynucleotide combining antisense and decoy approaches to target both TGF $\beta 1$ and Smad3 [105]. This approach inhibited both translation of TGF $\beta 1$ mRNA and Smad 3 binding to promotors and was utilized to downregulate TGF $\beta 1$ expression and TGF $\beta 1$-dependant gene expression [105]. This resulted in repression of activation of hepatic stellate cells to a $\alpha$ SMA-positive myofibroblast phenotype, as well as suppression of fibronectin and collagen I expression, deposition of collagen fibrils, and attenuation of fibrogenesis in vivo in the $\mathrm{CCl}_{4}$-treated model of liver cirrhosis [105].

\subsection{Connexin 43}

Connexin43 expression has also been suppressed using AOs, leading to reduced scarring in the eyes and skin after damage [66,68]. In the case of partial thickness burn wounds, this effect appears to be mediated by suppressing the inflammatory response, with reduced neutrophil numbers at early time points after injury [66]. This appears to facilitate tissue healing and prevent fibrosis as the proliferation of epidermal cells was enhanced and the re-epithelialization of the wound was accelerated in treated tissue compared to controls [66]. AOs have also been utilized to knockdown expression of endogenous connexin 43 to demonstrate the TGF $\beta 1$-mediated induction of $\alpha$ SMA transcriptional activity in vivo [63]. Additionally, AO-mediated knockdown of connexin43 after 
glaucoma trabeculectomy resulted in decreased $\alpha$ SMA expression, reduced myofibroblast activity, as well as less densely packed collagen compared to controls [68].

\section{6. $\mathrm{miRs}$}

Anti-miR or antagomir AOs have been used in several studies to target miRs in the hope of amelioration of fibrosis. For example, AOs have been utilized to target miR-21 in cardiac, kidney, and lung fibrosis $[76,106,107]$. Treatment with an anti-miR-21 AO resulted in downregulated expression of pro-fibrotic factors, such as collagens and other ECM constituents, in a pressure-overload-induced mouse model of cardiac fibrosis [106]. Similar results were seen in response to treatment with anti-miR-21 AOs in UUO- and ischemia/reperfusion injury-induced mouse models of renal fibrosis, with down regulation of collagens I and III observed [107], as well as in bleomycin-induced pulmonary fibrosis in mice, where upon AO treatment the pro-fibrogenic activity of TGF $\beta 1$ was reduced and deposition of ECM components, such as fibronectin and collagen, was suppressed [76]. Alongside these studies, other groups have used AOs to target other miRs for the suppression of fibrosis. In a mouse model of diabetic nephropathy, treatment with AOs targeting miR-192 decreased expression of TGF $\beta 1$, collagens, and fibronectin [75]. Anti-miR-208a AOs attenuated periarteriolar fibrosis in a model of rat heart failure [108]; while cardiac fibrosis was ameliorated in response to anti-miR-15 AO treatment in mice following ischemic injury [109]. Finally, AO-mediated inhibition of miR-34a appeared to reduce fibrosis following myocardial infarction in rats [110]; while targeting miR-34a, $-\mathrm{b}$ and -c likewise reduced cardiac fibrosis improved systolic function in mice subjected to pressure overload [111].

\section{The Use of AOs to Target Expression of Downstream Fibrotic Mediators of TGF $\beta 1$}

Additionally, other studies have sought to address fibrosis using AOs to downregulate expression of downstream pro-fibrotic effectors of TGF $\beta 1$, such as CTGF, periostin and TIMPs.

\subsection{CTGF}

Expression of the cytokine CTGF is undetectable in normal tissue but is promoted in wounded tissue before returning to basal levels following completion of tissue repair [112]. This upregulation of CTGF expression is correlated with the development of fibrosis in various disorders and models affecting different tissues including skin [113,114], liver [115], kidney [116], lung [53], and muscle [117]. This increase in CTGF expression appears to be induced by TGF $\beta 1$, and CTGF seems to function as a downstream fibrotic-mediator of TGF $\beta 1$ [52-56]. Indeed, it has been demonstrated that the induction of CTGF by TGF $\beta 1$ is mediated by a unique TGF $\beta 1$ response element within the CTGF gene promotor sequence [52].

CTGF therefore represents a potential target, downstream of TGF $\beta 1$, for the inhibition of fibrosis. A range of strategies have been investigated for suppression of CTGF expression or activity, including neutralizing anti-CTGF monoclonal antibodies [118-121] and CTGF-targeted small interfering RNAs [122-124]. Additionally, AOs have been utilized to block expression of endogenous CTGF for the suppression of fibrogenesis in multiple systems. For example, TGF $\beta 1$-induced expression of fibronectin and collagen I appears attenuated in vitro in rat renal fibroblasts via repression of CTGF expression using CTGF-targeting AOs [125,126]. Likewise, in vivo treatment with CTGF-targeting AOs reduced expression and interstitial deposition of ECM constituents, such as fibronectin and collagen I, reduced expression of $\alpha$-SMA, and ameliorated development of renal fibrogenesis after UUO in rat and mouse models of diabetic nephropathy $[127,128]$. Furthermore, CTGF-targeted AOs also abrogated hypertrophic scarring in rabbit wound models [129], and inhibited collagen III expression, ameliorated fibrosis, and improved function during murine flexor tendon repair [95].

\subsection{Periostin}

The matricellular protein periostin (also known as osteoblast-specific factor 2), which was first identified in a screen of a mouse osteoblastic library, is normally expressed in the periodontal 
ligament and the periosteum, where it functions to modulate cell-ECM interactions and cellular response to external stimuli [130-134]. Periostin evidently serves in the normal tissue repair process across the body [57,135-137], but is also associated with fibrosis in multiple pathological conditions affecting different organs, including the heart [138-141], lung [58,142,143], kidney [17], skin [57], and muscle [137].

Within the ECM, periostin interacts with collagens I and V, fibronectin and tenascin C $[142,144,145]$. Additionally, periostin can stimulate collagen fibrillogenesis and crosslinking through interactions with BMP1, which promotes the proteolytic activation of lysyl oxidase, the enzyme responsible for collagen crosslinking [140,143-146]. Furthermore, periostin aids cell motility by serving as a ligand for integrins, such as $\alpha v \beta 3$ and $\alpha v \beta 5$ [140,147-150]. During acute injury, expression of periostin is temporarily induced by TGF $\beta 1$ (as well as other factors such as interleukin-4 and interleukin-3) [57,58,142]. After induction, periostin stimulates migration of cells such as myofibroblasts, while also serving to create a scaffold, using fibronectin, for the crosslinking of type I collagen, which engenders remodeling of ECM architecture and contributes to tissue repair. However, during chronic injury, due to persistent damage or stress, levels of periostin remain elevated, which contributes to the development of fibrosis in this context.

Since upregulated periostin expression is evidently associated with fibrogenesis, this pro-fibrotic factor is an attractive anti-fibrotic target downstream of TGF $\beta 1$. AOs were utilized to inhibit periostin in an $N^{\mathrm{G}}$-nitro-L-arginine methyl ester hydrochloride (L-NAME)-induced rat model of chronic kidney disease (CKD), with treated rats showing reduce fibrosis and tubular dilation [17]. Furthermore, a later study showed that diabetic mice treated with periostin-binding DNA aptamers displayed lower levels of renal fibrosis arising from diabetic nephrology [151]. Specifically, the DNA aptamers abrogated significant increases in fibronectin and collagen I mRNA and protein levels, while tubulointerstitial fibrosis was significantly reduced in treated mice [151]. In another mouse model of fibrosis, namely adhesion formation following abdominal surgery, treatment with periostin-targeting AOs significantly reduced adhesion formation 14 days after surgery, as well as significantly reducing TGF $\beta 1$ and collagen I levels, compared to saline or negative sense oligonucleotide treated mice [152]. Likewise, bleomycin-induced pulmonary fibrosis was effectively suppressed using intrathecally administered AOs targeting periostin, a treatment which also inhibited the metastatic colonization of the lung by melanoma cells [153]. The role of periostin in metastasis is well established (reviewed by Ratajczak-Wielgomas and Dziegiel, 2015) [154]. In line with this, inhibition of periostin using promoter-directed small antisense non-coding RNAs in vitro prevented the exponential expansion and motility of tumor cells [155].

\subsection{TIMPS}

MMPs are a large group of proteinases that are capable of degrading various kinds of ECM components, and which regulate ECM remodeling [156,157]. In healthy tissue, during wound healing, and in fibrotic tissues, the activity of MMPs is determined by the amount of active protein and the concentration of TIMPs, specific MMP inhibitors [157]. TIMPs are also involved in various biological processes such as cell survival, apoptosis, cell invasion, cell migration, cell growth and differentiation, and angiogenesis [157]. The TIMP family members include TIMP1-4, with TIMP1 and TIMP2 serving to protect components of the ECM from proteolysis through inhibition of MMP9 and MMP2 respectively [158,159]. TIMPs also function in their own right to enhance collagen synthesis [157]. Given their apparent role in regulation of ECM components and architecture, TIMPs represent potential targets for anti-fibrotic approaches.

For example, an antisense TIMP1 cDNA delivered using retroviral vector via intratracheal injection has been reported to suppress the early stages of fibrosis in the bleomycin-induced rat model of pulmonary fibrosis [160]. Up to three days post-bleomycin treatment, TIMP1 expression and hydroxyproline content were significantly decreased in lung tissue compared to controls [160]. Additionally, in rat models of hepatic fibrosis, AOs have been successfully used to suppress expression 
of both TIMP1 and TIMP2 [161,162]. It should be noted that on histological examination and by serum liver function index measurement, AOs targeting TIMP2 not only reduced hepatic fibrosis but also acted to improve liver function [162]. This may be due to its specific inhibition of MMP2 which is important in the synthesis and degradation of collagen IV in liver fibrosis [162].

\section{Future Perspectives}

AOs have been exploited pre-clinically to target several pro-fibrotic genes with in vitro and in vivo demonstrations of efficacy (see Table 1 for a summary of this).

Table 1. Summary of profibrotic factors that have been targeted with AOs.

\begin{tabular}{|c|c|c|c|}
\hline Pro-Fibrotic Factor & Function & Model & References \\
\hline \multirow{3}{*}{ TGF $\beta 1$} & \multirow{3}{*}{$\begin{array}{l}\text { Pro-fibrotic } \\
\text { master-regulator }\end{array}$} & In vitro and in vivo rodent models of renal fibrosis & [92-94] \\
\hline & & In vivo mouse model of tendon scarring & [95] \\
\hline & & In vitro models of hepatic fibrosis & [96] \\
\hline \multirow[b]{2}{*}{ ALK5 } & \multirow{2}{*}{$\begin{array}{l}\text { Component of canonical } \\
\text { TGF } \beta 1 \text { receptor-TGF } \beta 1 \\
\text { signaling }\end{array}$} & Ex vivo in cultures of Dupuytren's patient tissue & [91] \\
\hline & & In vivo mouse model of DMD & [102] \\
\hline \multirow{3}{*}{ SMAD3 } & \multirow{3}{*}{$\begin{array}{l}\text { Component of canonical } \\
\text { TGF } \beta 1 \text { signaling } \\
\text { pathway }\end{array}$} & In vitro culture of human keloid fibroblasts & [104] \\
\hline & & In vivo mouse model of tendon scarring & [95] \\
\hline & & In vitro and in vivo mouse models of renal fibrosis & [105] \\
\hline \multirow{3}{*}{ Connexin 43} & \multirow{3}{*}{$\begin{array}{l}\text { Component of gap } \\
\text { junctions-pro-fibrotic } \\
\text { factor }\end{array}$} & In vitro culture of rat cardiac fibroblasts & {$[63]$} \\
\hline & & In vivo model of rabbit eye glaucoma trabeculectomy & [68] \\
\hline & & In vivo neonatal mouse model of burn injury & [66] \\
\hline \multirow{3}{*}{$\operatorname{miR}-21$} & \multirow{3}{*}{ Pro-fibrotic miR } & In vivo mouse model of cardiac fibrosis & [106] \\
\hline & & In vivo mouse models of renal fibrosis & [107] \\
\hline & & In vivo mouse models of pulmonary fibrosis & [76] \\
\hline miR-192 & Pro-fibrotic miR & In vivo mouse models of renal fibrosis & [75] \\
\hline miR-208a & Pro-fibrotic miR & In vivo rodent models of vascular and cardiac fibrosis & {$[108,109]$} \\
\hline miR-34 & Pro-fibrotic miR & In vivo mouse and rat models of cardiac fibrosis & {$[110,111]$} \\
\hline \multirow{3}{*}{ CTGF } & \multirow{3}{*}{$\begin{array}{l}\text { Downstream pro-fibrotic } \\
\text { effector of TGF } \beta 1\end{array}$} & In vivo neonatal mouse model of burn injury & {$[66]$} \\
\hline & & In vivo rabbit model of hypertrophic scarring & [129] \\
\hline & & In vivo mouse model of tendon scarring & [95] \\
\hline \multirow{5}{*}{ Periostin } & \multirow{5}{*}{$\begin{array}{l}\text { Downstream pro-fibrotic } \\
\text { effector of TGF } \beta 1\end{array}$} & In vivo rat model of renal injury & [17] \\
\hline & & In vivo mouse model of renal fibrosis & {$[151]$} \\
\hline & & In vivo mouse model of surgically induced adhesions & {$[152]$} \\
\hline & & In vivo mouse model of pulmonary fibrosis & {$[153]$} \\
\hline & & Cultures of multiple human cell lines & [155] \\
\hline \multirow{2}{*}{ TIMPs } & \multirow{2}{*}{$\begin{array}{l}\text { MMP inhibitors and } \\
\text { pro-fibrotic factors }\end{array}$} & In vivo rat model of pulmonary fibrosis & [160] \\
\hline & & In vivo rat model of hepatic fibrosis & {$[161,162]$} \\
\hline $\mathrm{bFGF}^{*}$ & $\begin{array}{l}\text { Cytokine-pro-fibrotic } \\
\text { factor }\end{array}$ & In vivo rat model of pulmonary fibrosis & [163] \\
\hline Kras* & $\begin{array}{l}\text { Monomeric GTPase- } \\
\text { component of signal } \\
\text { transduction pathways }\end{array}$ & In vivo rat model of renal fibrosis & [164] \\
\hline Sp1 ${ }^{*}$ & Transcription factor & $\begin{array}{l}\text { In vitro culture of human dermal fibroblasts and in vivo in } \\
\text { murine skin }\end{array}$ & [165] \\
\hline \multirow{2}{*}{ NF-kB * } & \multirow{2}{*}{ Transcription factor } & In vivo mouse model of pulmonary fibrosis & {$[166]$} \\
\hline & & In vivo mouse model of interstitial fibrosis & [167] \\
\hline STAT1 * & Transcription factor & In vivo rat model of pulmonary fibrosis & {$[168]$} \\
\hline $\mathrm{HSP} 27$ * & Chaperone & In vitro and in vivo rat model of pulmonary fibrosis & [169] \\
\hline
\end{tabular}


Several features make the antisense approach an attractive strategy to pursue further. These advantages include flexibility in dosage, frequency of dosing, non-immunogenicity upon repeat administration, and transient effect. Perhaps most importantly, they could hold a possible preferential path to clinics since AOs for the treatment of genetic diseases, such as DMD and spinal muscular atrophy, are either in trial or have even approved [8]. One particular benefit of the use of AOs is that the transient nature of the target knockdown affords ease of dose manipulation. This would allow the removal of target inhibition when required, such as during times of injury, surgery, or other assault to non-fibrotic tissues, to ensure efficient repair can proceed. In particular, this may be necessary when using anti-fibrotic AOs in contexts when fibrosis is an accompanying pathological feature of disease, but not the direct cause, as is the case in some inherited disorders such as DMD. In these circumstances, the inhibition of pro-fibrotic mediators may interfere with or delay normal wound healing upon injury to tissues unaffected by the disorder. To allow tissue repair to proceed it would be expedient to suspend treatment, and the $\mathrm{AO}$ approach would easily allow for this possibility. Overall, the advantages of AOs make the antisense approach attractive compared to the limitations of other approaches, such as immunological blockade. For example, while AOs are non-immunogenic, antibodies are potentially immunogenic upon repeated treatment, although this can be minimized through use of humanized antibodies.

Additionally, in contrast to AOs being developed to treat certain genetic diseases, it is possible that with the right target, one $\mathrm{AO}$ could have a general application to fibrosis across a range of tissues, potentially leading to more rapid approval clinically for the treatment of a number fibrotic disorders. However, it is acknowledged that there is some diversity in the fibrotic pathways in different tissues, and so it is unlikely that one $\mathrm{AO}$ will treat all fibrotic disorders. Furthermore, due to the variety of pro-fibrotic pathways, it is likely that fibrosis in different tissues will respond differently to knockdown of the same target because of the interplay of other pathways specific to each tissue type. As such, it is likely that for effective targeting of fibrosis in any one tissue, more than one pro-fibrotic protein will need to be inhibited simultaneously. It should be noted that these issues would hold irrespective of the anti-fibrotic targeting strategy developed, be it AO, antibody, small molecule inhibitor or another approach. Nevertheless, it may be the case that the different knockdown strategies will behave differently in different tissues due to variations in tissue-specific fibrotic mechanisms. As such, it may be necessary to utilize a mixture of knockdown strategies for different targets in any one tissue. Finally, it would be of immense benefit and interest if a direct comparison of the different strategies available for knockdown for each target in each tissue was undertaken.

Other modes of targeting fibrosis, for example, using monoclonal antibodies, small chemicals, and enzyme inhibitors, have reached clinical trial with varying success [7]. This variability is largely attributable to the target addressed. For example, in a phase I/II trial, systemic sclerosis patients treated with a neutralizing anti-TGF $\beta 1$ antibody showed a significant increase in serious adverse events compared to those receiving placebo, while another trial discontinued early due to lack of efficacy $[79,80]$. Similarly, a clinical trial for DMD using a soluble myostatin receptor also reported adverse events and was eventually terminated due to potential safety concerns of epistaxis and telangiectasia [170]. In contrast, in trials, immunological blockade of CTGF proved to be more successful $[118,121]$. The same is likely to be true for AO-mediated knockdown of expression. A potential key conceptual advantage of targeting TGF $\beta 1$, or components of the TGF $\beta$ signaling cascade such as ALK5 or Smad5, is that this would suppress expression of a wide-range of downstream pro-fibrotic genes at the same time. However, TGF $\beta 1$ functions as a pleiotropic factor [171]. This potentially may result in adverse effects and is likely the reason for the events observed in the anti-TGF $\beta 1$ antibody trials [79,80]. It is probable that similar events would occur upon targeting components of the TGF $\beta$ signaling cascade as these factors are also involved in other biological processes in addition to fibrosis. A further source of concern is that mice in which the TGF $\beta 1$ gene is disrupted develop a wasting syndrome involving tissue necrosis, a multifocal inflammatory response in various organs, and eventual death [172]. This suggests that TGF $\beta 1$ does not represent a suitable target for anti-fibrotic therapeutic interventions. Additionally, 
some other pro-fibrotic targets summarized in Table 1, such as Kras and NF- $\mathrm{B}$, are involved in a range of cellular functions in addition to fibrosis. As such, these are also less attractive targets as their inhibition may affect other processes as well as fibrosis. In contrast, downstream pro-fibrotic mediators of TGF $\beta 1$, such as CTGF and periostin, could represent better targets due to their narrower range of functions. Thus, it is the opinion of the authors that the choice of target for any successful AO-mediated anti-fibrotic approach is critical, and that downstream mediators of TGF $\beta 1$ signaling, such as CTGF, are likely to be better targets than TGF $\beta 1$ itself.

Despite the apparent advantages and promise of AOs as anti-fibrotics, it must be acknowledged that to this point none of the anti-fibrotic AOs used in pre-clinical studies have reached clinical trial, despite the evident success of antisense therapy for inherited disorders. This disparity is likely to be due to the need for greater anti-fibrotic effects to be demonstrated in disease models than has been achieved to date. It is also evident that several different AOs targeting the same pro-fibrotic factor have been reported. A more concerted effort between groups to ensure that the optimal AO is trialed more comprehensively pre-clinically may accelerate the route to clinical trial.

Additionally, several drawbacks of the antisense strategy are evident. For instance, the potential benefits may be offset by limits to efficacy and associated toxicities of AOs [173,174]. Indeed, for fibrosis-targeting AOs to reach the clinic, enhancing efficacy and minimizing toxicity through optimization of targeted AO chemistry and delivery needs to be addressed. Nevertheless, much effort has been made to increase efficacy and mitigate potential toxicities, particularly through attempts to increase cellular uptake. Approaches, including conjugation of AOs to aptamers, cell-penetrating peptides, and antibodies, are currently being explored for those targeting disease causing mutations, such as those seen in DMD $[97,98,175]$. However, while myostatin-targeting AOs have been delivered using a peptide-conjugate delivery system in neonatal and adult $m d x$ mice $[97,98]$, to the knowledge of the authors, these strategies have not to this point been used to increase cellular uptake of AOs targeting other components of the TGF $\beta$ signaling pathway. Nevertheless, such approaches should easily be applied to AOs showing greatest efficacy against fibrosis. For instance, the development of cell-penetrating peptides in the past decade has successfully enhanced specific delivery of AOs in preclinical studies and holds promise to improve anti-fibrotic antisense therapy in the future in terms of improved efficacy and reduced toxicity [97,176-179].

Additionally, in many fibrotic conditions, addressing the fibrotic component of the disorder will not necessarily be corrective for the underlying disease etiology. For instance, in the context of DMD, targeting fibrosis will not correct the essential genetic defect, but merely mitigate some of the resulting effects. As such, combinatorial strategies should be developed that address both the fibrotic element of a disorder as well as the basic cause. Such an antisense approach has already been investigated with regards to recovering dystrophin expression and for myostatin knockdown to increase muscle mass as a potential treatment for DMD [97,98]. Furthermore, it may be pertinent to extend combinatorial strategies to cover other aspects of disease pathology. For example, there could be some benefit to use AOs to target inflammatory factors, particularly due to the role of inflammation in initiating the fibrotic cascade (ass Figure 1a). However, given the critical biological role of such factors, care should be taken.

Finally, as with most other therapies, an antisense approach would not reverse fibrosis, and would merely prevent further development of pathological fibrotic alterations to tissue architecture. Therefore, it is likely that prophylactic AO treatment would ideally be commenced upon diagnosis of a disease that has fibrosis as a pathophysiological component. For example, in the muscular dystrophies the genetic diagnosis is generally made before the onset of muscle fibrosis, while in diabetic kidney disease and fatty liver disease, fibrosis is also seen in the latter stages of these conditions. Early anti-fibrotic treatment is also critical because as fibrosis becomes established, deposited ECM may prevent cellular uptake of the therapeutic agent used to treat a disease. As such, an anti-fibrotic AO may only be effective at pre- and early-fibrotic stages. It is hoped that early treatment with AOs, or indeed any other therapy targeting pro-fibrotic signaling, would prevent the life-threatening 
consequences of the development of fibrosis in many different conditions, and should be further explored to improve treatment outcomes, enhance the quality of life of patients, and prolong life expectancy. In terms of healthcare, it will mean relief of the immense pressure for liver, kidney, heart, and lung transplantations, with associated savings in costs for treatments. We would therefore advocate that AO-targeted inhibition of pro-fibrotic protein expression holds realistic potential but would recommend that international cross-disease collaboration will be vital to achieve this aim.

Acknowledgments: The authors acknowledge Muscular Dystrophy UK for their support of research performed at Royal Holloway University of London in the fibrosis area. We also acknowledge the editorial assistance of Naomi March.

Conflicts of Interest: The authors declare no conflict of interest.

\section{References}

1. Kumar, S. Cellular and molecular pathways of renal repair after acute kidney injury. Kidney Int. 2018, 93, 27-40. [CrossRef] [PubMed]

2. Walraven, M.; Hinz, B. Therapeutic approaches to control tissue repair and fibrosis: Extracellular matrix as a game changer. Matrix Biol. 2018. [CrossRef] [PubMed]

3. Wynn, T.A. Cellular and molecular mechanisms of fibrosis. J. Pathol. 2008, 214, 199-210. [CrossRef] [PubMed]

4. Kawano, H.; Kimura-Kuroda, J.; Komuta, Y.; Yoshioka, N.; Li, H.; Kawamura, K.; Raisman, G. Role of the lesion scar in the response to damage and repair of the central nervous system. Cell Tissue Res. 2012, 349, 169-180. [CrossRef] [PubMed]

5. Rockey, D.C.; Bell, P.D.; Hill, J.A. Fibrosis-A common pathway to organ injury and failure. N. Engl. J. Med. 2015, 373, 1138-1149. [CrossRef] [PubMed]

6. Murtha, L.A.; Schuliga, M.J.; Mabotuwana, N.S.; Hardy, S.A.; Waters, D.W.; Burgess, J.K.; Knight, D.A.; Boyle, A.J. The processes and mechanisms of cardiac and pulmonary fibrosis. Front. Physiol. 2017, 8, 777. [CrossRef] [PubMed]

7. Li, X.; Zhu, L.; Wang, B.; Yuan, M.; Zhu, R. Drugs and targets in fibrosis. Front. Pharmacol. 2017, 8. [CrossRef] [PubMed]

8. Havens, M.A.; Hastings, M.L. Splice-switching antisense oligonucleotides as therapeutic drugs. Nucleic Acids Res. 2016, 44. [CrossRef] [PubMed]

9. Horbelt, D.; Denkis, A.; Knaus, P. A portrait of transforming growth factor $\beta$ superfamily signalling: Background matters. Int. J. Biochem. Cell Biol. 2012, 44, 469-474. [CrossRef] [PubMed]

10. Walton, K.L.; Johnson, K.E.; Harrison, C.A. Targeting TGF- $\beta$ mediated SMAD signaling for the prevention of fibrosis. Front. Pharmacol. 2017, 8. [CrossRef] [PubMed]

11. Roberts, A.B.; Sporn, M.B.; Assoian, R.K.; Smith, J.M.; Roche, N.S.; Wakefield, L.M.; Heine, U.I.; Liotta, L.A.; Falanga, V.; Kehrl, J.H. Transforming growth factor type beta: Rapid induction of fibrosis and angiogenesis in vivo and stimulation of collagen formation in vitro. Proc. Natl. Acad. Sci. USA 1986, 83, 4167-4171. [CrossRef] [PubMed]

12. Meng, X.; Nikolic-Paterson, D.J.; Lan, H.Y. TGF- $\beta$ : The master regulator of fibrosis. Nat. Rev. Nephrol. 2016, 4, 325-338. [CrossRef] [PubMed]

13. Broekelmann, T.J.; Limper, A.H.; Colby, T.V.; McDonald, J.A. Transforming growth factor $\beta_{1}$ is present at sites of extracellular matrix gene expression in human pulmonary fibrosis. Proc. Natl. Acad. Sci. USA 1991, 88, 6642-6646. [CrossRef] [PubMed]

14. Sime, P.J.; Xing, Z.; Graham, F.L.; Csaky, K.G.; Gauldie, J. Adenovector-mediated gene transfer of active transforming growth factor- $\beta 1$ induces prolonged severe fibrosis in rat lung. J. Clin. Investig. 1997, 100, 768-776. [CrossRef] [PubMed]

15. Czaja, M.J.; Weiner, F.R.; Flanders, K.C.; Giambrone, M.A.; Wind, R.; Biempica, L.; Zern, M.A. In vitro and in vivo association of transforming growth factor-beta 1 with hepatic fibrosis. J. Cell Biol. 1989, 108, 2477-2482. [CrossRef] [PubMed]

16. Hayasaka, A.; Suzuki, N.; Fukuyama, E.; Kanda, Y. Plasma levels of transforming growth factor $\beta 1$ in chronic liver disease. Clin. Chim. Acta 1996, 244, 117-119. [CrossRef] 
17. Mael-Ainin, M.; Abed, A.; Conway, S.J.; Dussaule, J.; Chatziantoniou, C. Inhibition of periostin expression protects against the development of renal inflammation and fibrosis. JASN 2014, 25, 1724-1736. [CrossRef] [PubMed]

18. Lijnen, P.J.; Petrov, V.V.; Fagard, R.H. Induction of cardiac fibrosis by transforming growth factor- $\beta 1$. Mol. Genet. MeTab. 2000, 71, 418-435. [CrossRef] [PubMed]

19. Khan, S.; Joyce, J.; Margulies, K.B.; Tsuda, T. Enhanced bioactive myocardial transforming growth factor-beta in advanced human heart failure. Circ. J. 2014, 78, 2711-2718. [CrossRef] [PubMed]

20. Yamazaki, M.; Minota, S.; Sakurai, H.; Miyazono, K.; Yamada, A.; Kanazawa, I.; Kawai, M. Expression of transforming growth factor-beta 1 and its relation to endomysial fibrosis in progressive muscular dystrophy. Am. J. Pathol. 1994, 144, 221-226. [PubMed]

21. Bernasconi, P.; Torchiana, E.; Confalonieri, P.; Brugnoni, R.; Barresi, R.; Mora, M.; Cornelio, F.; Morandi, L.; Mantegazza, R. Expression of transforming growth factor-beta 1 in dystrophic patient muscles correlates with fibrosis. Pathogenetic role of a fibrogenic cytokine. J. Clin. Investig. 1995, 96, 1137-1144. [CrossRef] [PubMed]

22. Ishitobi, M.; Haginoya, K.; Zhao, Y.; Ohnuma, A.; Minato, J.; Yanagisawa, T.; Tanabu, M.; Kikuchi, M.; Linuma, K. Elevated plasma levels of transforming growth factor beta1 in patients with muscular dystrophy. Neuroreport 2000, 11, 4033-4035. [CrossRef] [PubMed]

23. Grobet, L.; Martin, L.J.; Poncelet, D.; Pirottin, D.; Brouwers, B.; Riquet, J.; Schoerberlein, A.; Dunner, S.; Menissier, F.; Massabanda, J.; et al. A deletion in the bovine myostatin gene causes the double-muscled phenotype in cattle. Nat. Genet. 1997, 17, 71-74. [CrossRef] [PubMed]

24. Mcpherron, A.C.; Lee, S.J. Double muscling in cattle due to mutations in the myostatin gene. Proc. Natl. Acad. Sci. USA 1997, 94, 12457-12461. [CrossRef] [PubMed]

25. Schuelke, M.; Wagner, K.R.; Stolz, L.E.; Hübner, C.; Riebel, T.; Kömen, W.; Braun, T.; Tobin, J.F.; Lee, S.J. Myostatin mutation associated with gross muscle hypertrophy in a child. N. Engl. J. Med. 2004, 350, 2682-2688. [CrossRef] [PubMed]

26. Mosher, D.S.; Quignon, P.; Bustamante, C.D.; Sutter, N.B.; Mellersh, C.S.; Parker, H.G.; Ostrander, E.A. A mutation in the myostatin gene increases muscle mass and enhances racing performance in heterozygote dogs. PLoS Genet. 2007, 3, e79. [CrossRef] [PubMed]

27. Bogdanovich, S.; Thomas, O.B.K.; Barton, E.R.; Morris, L.D.; Whittemore, L.; Ahima, R.S. Functional improvement of dystrophic muscle by myostatin blockade. Nature 2002, 420, 418-421. [CrossRef] [PubMed]

28. Liu, C.M.; Yang, Z.; Liu, C.W.; Wang, R.; Tien, P.; Dale, R. Myostatin antisense RNA-mediated muscle growth in normal and cancer cachexia mice. Gene Ther. 2008, 15, 155-160. [CrossRef] [PubMed]

29. Guo, T.; Jou, W.; Chanturiya, T.; Portas, J.; Gavrilova, O.; McPherron, A.C. Myostatin inhibition in muscle, but not adipose tissue, decreases fat mass and improves insulin sensitivity. PLoS ONE 2009, 4, e4937. [CrossRef] [PubMed]

30. Smith, R.C.; Lin, B.K. Myostatin inhibitors as therapies for muscle wasting associated with cancer and other disorders. Curr. Opin. Support. Palliat. Care 2013, 7, 352-360. [CrossRef] [PubMed]

31. Butcher, J.T.; Ali, M.I.; Ma, M.W.; McCarthy, C.G.; Islam, B.N.; Fox, L.G.; Mintz, J.D.; Larion, S.; Fulton, D.J.; Stepp, D.W. Effect of myostatin deletion on cardiac and microvascular function. Physiol. Rep. 2017, 5. [CrossRef] [PubMed]

32. Pirruccello-Straub, M.; Jackson, J.; Wawersik, S.; Webster, M.; Salta, L.; Long, K.; McConaughy, W.; Capili, A.; Boston, C.; Carven, G.; et al. Blocking extracellular activation of myostatin as a strategy for treating muscle wasting. Sci. Rep. 2018, 8, 2292. [CrossRef] [PubMed]

33. Wagner, K.R.; Mcpherron, A.C.; Winik, N.; Lee, S. Loss of myostatin attenuates severity of muscular dystrophy in mdx mice. Ann. Neurol. 2002, 52, 832-836. [CrossRef] [PubMed]

34. Qiao, C.; Li, J.; Jiang, J.; Zhu, X.; Wang, B.; Li, J.; Xiao, X. Myostatin propeptide gene delivery by adeno-associated virus serotype 8 vectors enhances muscle growth and ameliorates dystrophic phenotypes in mdx mice. Hum. Gene Ther. 2008, 19, 241-254. [CrossRef] [PubMed]

35. Li, Z.B.; Kollias, H.D.; Wagner, K.R. Myostatin directly regulates skeletal muscle fibrosis. J. Biol. Chem. 2008, 283, 19371-19378. [CrossRef] [PubMed]

36. McPherron, A.C.; Lawler, A.M.; Lee, S. Regulation of skeletal muscle mass in mice by a new TGF-beta superfamily member. Nature 1997, 386, 83-90. [CrossRef] [PubMed] 
37. Al-Zaidy, S.A.; Sahenk, Z.; Rodino-Klapac, L.R.; Kaspar, B.; Mendell, J.R. Follistatin gene therapy improves ambulation in becker muscular dystrophy. J. Neuromuscul. Dis. 2015, 2, 185-192. [CrossRef] [PubMed]

38. Robertson, I.B.; Horiguchi, M.; Zilberberg, L.; Dabovic, B.; Hadjiolova, K.; Rifkin, D.B. Latent TGF-beta-binding proteins. Matrix Biol. 2015, 47, 44-53. [CrossRef] [PubMed]

39. Annes, J.P.; Munger, J.S.; Rifkin, D.B. Making sense of latent TGFbeta activation. J. Cell Sci. 2003, 116, $217-224$. [CrossRef] [PubMed]

40. Le, V.Q.; Iacob, R.E.; Tian, Y.; Mcconaughy, W.; Jackson, J.; Su, Y.; Zhao, B.; Engen, J.R.; Pirruccello-Straub, M.; Springer, T.A. Tolloid cleavage activates latent GDF8 by priming the pro-complex for dissociation. EMBO J. 2018, 37, 384-397. [CrossRef] [PubMed]

41. Miyazawa, K.; Shinozaki, M.; Hara, T.; Furuya, T.; Miyazono, K. Two major Smad pathways in TGF- $\beta$ superfamily signalling. Genes Cells 2002, 7, 1191-1204. [CrossRef] [PubMed]

42. Langley, B.; Thomas, M.; Bishop, A.; Sharma, M.; Gilmour, S.; Kambadur, R. Myostatin inhibits myoblast differentiation by down-regulating MyoD expression. J. Biol. Chem. 2002, 277, 49831-49840. [CrossRef] [PubMed]

43. Ignotz, R.A.; Massague, J. Transforming growth factor- $\beta$ stimulates the expression of fibronectin and collagen and their incorporation into the extracellular matrix. J. Biol. Chem. 1986, 261, 4337-4435. [PubMed]

44. Hocevar, B.A.; Brown, T.L.; Howe, P.H. TGF-beta induces fibronectin synthesis through a c-Jun N-terminal kinase-dependent, Smad4-independent pathway. EMBO J. 1999, 18, 1345-1356. [CrossRef] [PubMed]

45. Verrecchia, F.; Chu, M.; Mauviel, A. Identification of novel TGF- $\beta$ / Smad gene targets in dermal fibroblasts using a combined cDNA microarray/promoter transactivation approach. J. Biol. Chem. 2001, 276, 17058-17062. [CrossRef] [PubMed]

46. Presser, L.D.; McRae, S.; Waris, G. Activation of TGF- $\beta 1$ promoter by hepatitis $C$ virus-induced AP-1 and Sp1: Role of TGF- $\beta 1$ in hepatic stellate cell activation and invasion. PLoS ONE 2013, 8, e56367. [CrossRef] [PubMed]

47. Schonherr, E.; Jarvelainen, H.T.; Sandell, L.J.; Wight, T.N. Effects of platelet-derived growth factor and transforming growth factor- $\beta 1$ on the synthesis of a large versican-like chondroitin sulfate proteoglycan by arterial smooth muscle cells. J. Biol. Chem. 1991, 266, 17640-17647. [PubMed]

48. Dadlani, H.; Ballinger, M.L.; Osman, N.; Getachew, R.; Little, P.J. Smad and p38 MAP kinase-mediated signaling of proteoglycan synthesis in vascular smooth muscle. J. Biol. Chem. 2008, 283, 7844-7852. [CrossRef] [PubMed]

49. Dennler, S.; Itoh, S.; Vivien, D.; ten Dijke, P.; Huet, S.; Gauthier, J. Direct binding of Smad3 and Smad4 to critical TGF $\beta$-inducible elements in the promoter of human plasminogen activator inhibitor-type 1 gene. EMBO J. 1998, 17, 3091-3100. [CrossRef] [PubMed]

50. Hua, X.; Liu, X.; Ansari, D.O.; Lodish, H.F. Synergistic cooperation of TFE3 and Smad proteins in TGF-ß-induced transcription of the plasminogen activator inhibitor-1 gene. Genes Dev. 1998, 12, 3084-3095. [CrossRef] [PubMed]

51. Margadant, C.; Sonnenberg, A. Integrin-TGF- $\beta$ crosstalk in fibrosis, cancer and wound healing. EMBO Rep . 2010, 11, 97-105. [CrossRef] [PubMed]

52. Grotendorst, G.; Okochi, H.; Hayashi, N. A novel transforming growth factor beta response element controls the expression of the connective tissue growth factor gene. Cell Growth Differ. 1996, 7, 469-480. [PubMed]

53. Lasky, J.A.; Ortiz, L.A.; Tonthat, B.; Hoyle, G.W.; Corti, M.; Athas, G.; Lungarella, G.; Brody, A.; Friedman, M. Connective tissue growth factor mRNA expression is upregulated in bleomycin-induced lung fibrosis. Am. J. Physiol. 1998, 275, 365-371. [CrossRef]

54. Chen, Y.; Blom, I.E.; Sa, S.; Goldschmeding, R.; Abraham, D.J.; Leask, A. CTGF expression in mesangial cells: Involvement of SMADs, MAP kinase, and PKC. Kidney Int. 2002, 62, 1149-5119. [CrossRef] [PubMed]

55. Paradis, V.; Dargere, D.; Bonvoust, F.; Vidaud, M.; Segarini, P.; Bedossa, P. Effects and regulation of connective tissue growth factor on hepatic stellate cells. Lab. Investig. 2002, 82, 767-774. [CrossRef] [PubMed]

56. Vial, C.; Zúñiga, LM.; Cabello-Verrugio, C.; Cañón, P.; Fadic, R.; Brandan, E. Skeletal muscle cells express the profibrotic cytokine connective tissue growth factor (CTGF/CCN2), which induces their dedifferentiation. J. Cell. Physiol. 2008, 215, 410-421. [CrossRef] [PubMed]

57. Zhou, H.; Wang, J.; Elliott, C.; Wen, W.; Hamilton, D.; Conway, S. Spatiotemporal expression of periostin during skin development and incisional wound healing: Lessons for human fibrotic scar formation. J. Cell Commun. Signal. 2010, 4, 99-107. [CrossRef] [PubMed] 
58. Naik, P.K.; Bozyk, P.D.; Bentley, J.K.; Popova, A.P.; Birch, C.M.; Wilke, C.A.; Fry, C.D.; White, E.S.; Sisson, T.H.; Tayob, N.; et al. Periostin promotes fibrosis and predicts progression in patients with idiopathic pulmonary fibrosis. Am. J. Physiol. 2012, 303, 1046-1056. [CrossRef] [PubMed]

59. Desmouliere, A.; Geinoz, A.; Gabbiani, F.; Gabbiani, G. Transforming growth factor- $\beta 1$ induces $\alpha$-smooth muscle actin expression in granulation tissue myofibroblasts and in quiescent and growing cultured fibroblasts. J. Cell Biol. 1993, 122, 103-111. [CrossRef] [PubMed]

60. Fan, J.; Ng, Y.; Hill, P.A.; Nikolic-Paterson, D.J.; Mu, W.; Atkins, R.C.; Lan, H.Y. Transforming growth factor- $\beta$ regulates tubular epithelial-myofibroblast transdifferentiation in vitro. Kidney Int. 1999, 56, 1455-1467. [CrossRef] [PubMed]

61. Klingler, W.; Jurkat-Rott, K.; Lehmann-Horn, F.; Schleip, R. The role of fibrosis in Duchenne muscular dystrophy. Acta Myol. 2012, 31, 184-195. [PubMed]

62. Bo Li, Z.; Zhang, J.; Wagner, K.R. Inhibition of myostatin reverses muscle fibrosis through apoptosis. J. Cell Sci. 2012, 125, 3957-3965. [CrossRef] [PubMed]

63. Asazuma-Nakamura, Y.; Dai, P.; Harada, Y.; Jiang, Y.; Hamaoka, K.; Takamatsu, T. Cx43 contributes to TGF- $\beta$ signaling to regulate differentiation of cardiac fibroblasts into myofibroblasts. Exp. Cell Res. 2009, 315, 1190-1199. [CrossRef] [PubMed]

64. Beyer, E.C. Connexin43: A protein from rat heart homologous to a gap junction protein from liver. J. Cell Biol. 1987, 105, 2621-2629. [CrossRef] [PubMed]

65. Evans, W.H.; De Vuyst, E.; Leybaert, L. The gap junction cellular internet: Connexin hemichannels enter the signalling limelight. Biochem. J. 2006, 397, 1-14. [CrossRef] [PubMed]

66. Coutinho, P.; Qiu, C.; Frank, S.; Wang, C.M.; Brown, T.; Green, C.R.; Becker, D.L. Limiting burn extension by transient inhibition of Connexin43 expression at the site of injury. Br. J. Plast. Surg. 2005, 58, 658-667. [CrossRef] [PubMed]

67. Chung, C.; Muramatsu, T.; Uekusa, T.; Sasaki, H.; Shimono, M. Inhibition of connexin 43 expression and function in cultured rat dental pulp cells by antisense oligonucleotide. Cell Tissue Res. 2007, 329, 295-300. [CrossRef] [PubMed]

68. Deva, N.; Zhang, J.; Green, C.; Danesh-Meyer, H. Connexin43 modulation inhibits scarring in a rabbit eye glaucoma trabeculectomy model. Inflammation 2012, 35, 1276-1286. [CrossRef] [PubMed]

69. Dai, P.; Nakagami, T.; Tanaka, H.; Hitomi, T.; Takamatsu, T. Cx43 mediates TGF- $\beta$ signaling through competitive Smads binding to microtubules. Mol. Biol. Cell 2007, 18, 2264-2273. [CrossRef] [PubMed]

70. Van Rooij, E.; Sutherland, L.B.; Thatcher, J.E.; DiMaio, J.M.; Naseem, R.H.; Marshall, W.S.; Hill, J.A.; Olson, E.N. Dysregulation of microRNAs after myocardial infarction reveals a role of miR-29 in cardiac fibrosis. Proc. Natl. Acad. Sci. USA 2008, 105, 13027-13032. [CrossRef] [PubMed]

71. Maurer, B.; Stanczyk, J.; Jungel, A.; Akhmetshina, A.; Trenkmann, M.; Brock, M.; Kowal-Bielecka, O.; Gay, R.E.; Michel, B.A.; Distler, J.H.; et al. MicroRNA-29, a key regulator of collagen expression in systemic sclerosis. Arthritis Rheum. 2010, 62, 1733-1743. [CrossRef] [PubMed]

72. Qin, W.; Chung, A.C.; Huang, X.R.; Meng, X.M.; Hui, D.S.; Yu, C.M.; Sung, J.J.; Lan, H.Y. TGF-beta/Smad3 signaling promotes renal fibrosis by inhibiting miR-29. J. Am. Soc. Nephrol. 2011, 22, 1462-1474. [CrossRef] [PubMed]

73. Cushing, L.; Kuang, P.P.; Qian, J.; Shao, F.; Wu, J.; Little, F.; Thannickal, V.J.; Cardoso, W.V.; Lu, J. miR-29 is a major regulator of genes associated with pulmonary fibrosis. Am. J. Respir. Cell Mol. Biol. 2011, 45, 287-294. [CrossRef] [PubMed]

74. Roderburg, C.; Urban, G.W.; Bettermann, K.; Vucur, M.; Zimmermann, H.; Schmidt, S.; Janssen, J.; Koppe, C.; Knolle, P.; Castoldi, M.; et al. Micro-RNA profiling reveals a role for miR-29 in human and murine liver fibrosis. Hepatology 2011, 53, 209-218. [CrossRef] [PubMed]

75. Putta, S.; Lanting, L.; Sun, G.; Lawson, G.; Kato, M.; Natarajan, R. Inhibiting microRNA-192 ameliorates renal fibrosis in diabetic nephropathy. J. Am. Soc. Nephrol. 2012, 23, 458-469. [CrossRef] [PubMed]

76. Liu, G.; Friggeri, A.; Yang, Y.; Milosevic, J.; Ding, Q.; Thannickal, V.J.; Kaminski, N.; Abraham, E. miR-21 mediates fibrogenic activation of pulmonary fibroblasts and lung fibrosis. J. Exp. Med. 2010, 207, 1589-1597. [CrossRef] [PubMed]

77. Pandit, K.V.; Milosevic, J.; Kaminski, N. MicroRNAs in idiopathic pulmonary fibrosis. Transl. Res. 2011, 157, 191-199. [CrossRef] [PubMed] 
78. Cohn, R.D.; van Erp, C.; Habashi, J.P.; Soleimani, A.A.; Klein, E.C.; Lisi, M.T.; Gamradt, M.; ap Rhys, C.M.; Holm, T.M.; Loeys, B.L.; et al. Angiotensin II type 1 receptor blockade attenuates TGF-beta-induced failure of muscle regeneration in multiple myopathic states. Nat. Med. 2007, 13, 204-210. [CrossRef] [PubMed]

79. Denton, C.P.; Merkel, P.A.; Furst, D.E.; Khanna, D.; Emery, P.; Hsu, V.M.; Silliman, N.; Streisand, J.; Powell, J.; Akesson, A.; et al. Recombinant human anti-transforming growth factor beta1 antibody therapy in systemic sclerosis: A multicenter, randomized, placebo-controlled phase I/II trial of CAT-192. Arthritis Rheum. 2007, 56, 323-333. [CrossRef] [PubMed]

80. Voelker, J.; Berg, P.H.; Sheetz, M.; Duffin, K.; Shen, T.; Moser, B.; Greene, T.; Blumenthal, S.S.; Rychlik, I.; Yagil, Y.; et al. Anti-TGF- $\beta 1$ antibody therapy in patients with diabetic nephropathy. J. Am. Soc. Nephrol. 2017, 28, 953-962. [CrossRef] [PubMed]

81. Llopiz, D.; Dotor, J.; Casares, N.; Bezunartea, J.; Díaz-Valdés, N.; Ruiz, M.; Aranda, F.; Berraondo, P.; Prieto, J.; Lasarte, J.J.; et al. Peptide inhibitors of transforming growth factor- $\beta$ enhance the efficacy of antitumor immunotherapy. Int. J. Cancer 2009, 125, 2614-2623. [CrossRef] [PubMed]

82. Yamada, M.; Kuwano, K.; Maeyama, T.; Yoshimi, M.; Hamada, N.; Fukumoto, J.; Egashira, K.; Hiasa, K.; Takayama, K.; Nakanishi, Y. Gene transfer of soluble transforming growth factor type II receptor by in vivo electroporation attenuates lung injury and fibrosis. J. Clin. Pathol. 2007, 60, 916-920. [CrossRef] [PubMed]

83. Latres, E.; Pangilinan, J.; Miloscio, L.; Bauerlein, R.; Na, E.; Potocky, T.B.; Huang, Y.; Eckersdorff, M.; Rafique, A.; Mastaitis, J.; et al. Myostatin blockade with a fully human monoclonal antibody induces muscle hypertrophy and reverses muscle atrophy in young and aged mice. Skeletal Muscle 2015, 5, 34. [CrossRef] [PubMed]

84. Bogdanovich, S.; Perkins, K.J.; Krag, T.O.; Whittemore, L.A.; Khurana, T.S. Myostatin propeptide-mediated amelioration of dystrophic pathophysiology. FASEB J. 2005, 19, 543-549. [CrossRef] [PubMed]

85. Nakatani, M.; Takehara, Y.; Sugino, H.; Matsumoto, M.; Hashimoto, O.; Hasegawa, Y.; Murakami, T.; Uezumi, A.; Takeda, S.; Noji, S.; et al. Transgenic expression of a myostatin inhibitor derived from follistatin increases skeletal muscle mass and ameliorates dystrophic pathology in mdx mice. FASEB J. 2008, 22, 477-487. [CrossRef] [PubMed]

86. Rodino-Klapac, L.R.; Haidet, A.M.; Kota, J.; Handy, C.; Kaspar, B.K.; Mendell, J.R. Inhibition of myostatin with emphasis on follistatin as a therapy for muscle disease. Muscle Nerve 2009, 39, 283-296. [CrossRef] [PubMed]

87. Chen, J.L.; Walton, K.L.; Hagg, A.; Colgan, T.D.; Johnson, K.; Qian, H.; Gregorevic, P.; Harrison, C.A. Specific targeting of TGF- $\beta$ family ligands demonstrates distinct roles in the regulation of muscle mass in health and disease. Proc. Natl. Acad. Sci. USA 2017, 114, E5266-E5275. [CrossRef] [PubMed]

88. Pistilli, E.E.; Bogdanovich, S.; Goncalves, M.D.; Ahima, R.S.; Lachey, J.; Seehra, J.; Khurana, T. Targeting the activin type IIB receptor to improve muscle mass and function in the mdx mouse model of Duchenne muscular dystrophy. Am. J. Pathol. 2011, 178, 1287-1297. [CrossRef] [PubMed]

89. Grygielko, E.T.; Martin, W.M.; Tweed, C.; Thornton, P.; Harling, J.; Brooks, D.P.; Laping, N.J. Inhibition of gene markers of fibrosis with a novel inhibitor of transforming growth factor- $\beta$ type I receptor kinase in puromycin-induced nephritis. J. Pharmacol. Exp. Ther. 2005, 313, 943-951. [CrossRef] [PubMed]

90. Petersen, M.; Thorikay, M.; Deckers, M.; van Dinther, M.; Grygielko, E.T.; Gellibert, F.; de Gouville, A.C.; Huet, S.; ten Dijke, P.; Laping, N.J. Oral administration of GW788388, an inhibitor of TGF- $\beta$ type I and II receptor kinases, decreases renal fibrosis. Kidney Int. 2008, 73, 705-715. [CrossRef] [PubMed]

91. Karkampouna, S.; Kruithof, B.P.; Kloen, P.; Obdeijn, M.C.; van Der Laan, A.M.A.; Tanke, H.J.; Kemaladewi, D.U.; Hoogaars, W.M.; Aartsma-Rus, A.; Clark, I.M.; et al. Novel Ex Vivo Culture Method for the Study of Dupuytren's Disease: Effects of TGF $\beta$ Type 1 Receptor Modulation by Antisense Oligonucleotides. Mol. Ther. Nucleic Acids 2014, 3, e142. [CrossRef] [PubMed]

92. Akagi, Y.; Isaka, Y.; Arai, M.; Kaneko, T.; Takenaka, M.; Moriyama, T.; Kaneda, Y.; Ando, A.; Orita, Y.; Kamada, T.; et al. Inhibition of TGF-beta 1 expression by antisense oligonucleotides suppressed extracellular matrix accumulation in experimental glomerulonephritis. Kidney Int. 1996, 50, 148-155. [CrossRef] [PubMed]

93. Isaka, Y.; Tsujie, M.; Ando, Y.; Nakamura, H.; Kaneda, Y.; Imai, E.; Hori, M. Transforming growth factor-beta 1 antisense oligodeoxynucleotides block interstitial fibrosis in unilateral ureteral obstruction. Kidney Int. 2000, 58, 1885-1892. [CrossRef] [PubMed] 
94. Han, D.C.; Hoffman, B.B.; Hong, SW.; Guo, J.; Ziyadeh, F.N. Therapy with antisense TGF- $\beta 1$ oligodeoxynucleotides reduces kidney weight and matrix mRNAs in diabetic mice. Am. J. Physiol. Renal. Physiol. 2000, 278, F628-F634. [CrossRef] [PubMed]

95. Loiselle, A.E.; Yukata, K.; Geary, M.B.; Kondabolu, S.; Shi, S.; Jonason, J.H.; Awad, H.A.; O’Keefe, R.J. Development of antisense oligonucleotide (ASO) technology against Tgf- $\beta$ signaling to prevent scarring during flexor tendon repair. J. Orthop. Res. 2015, 33, 859-866. [CrossRef] [PubMed]

96. Arias, M.; Lahme, B.; Van de Leur, E.; Gressner, AM.; Weiskirchen, R. Adenoviral delivery of an antisense RNA complementary to the $3^{\prime}$ coding sequence of transforming growth factor-beta1 inhibits fibrogenic activities of hepatic stellate cells. Cell Growth Differ. 2002, 13, 265-273. [PubMed]

97. Malerba, A.; Kang, J.K.; Mcclorey, G.; Saleh, A.F.; Popplewell, L.; Gait, M.J.; Wood, M.J.; Dickson, G. Dual myostatin and dystrophin exon skipping by morpholino nucleic acid oligomers conjugated to a cell-penetrating peptide is a promising therapeutic strategy for the treatment of Duchenne muscular dystrophy. Mol. Ther. Nucleic Acids 2012, 1, e62. [CrossRef] [PubMed]

98. Lu-Nguyen, N.B.; Jarmin, S.A.; Saleh, A.F.; Popplewell, L.; Gait, M.J.; Dickson, G. Combination antisense treatment for destructive exon skipping of myostatin and open reading frame rescue of dystrophin in neonatal mdx mice. Mol. Ther. 2015, 23, 1341-1348. [CrossRef] [PubMed]

99. Lu-Nguyen, N.; Malerba, A.; Popplewell, L.; Schnell, F.; Hanson, G.; Dickson, G. Systemic antisense therapeutics for dystrophin and myostatin exon splice modulation improve muscle pathology of adult $\mathrm{mdx}$ mice. Mol. Ther. Nucleic Acids 2017, 6, 15-28. [CrossRef] [PubMed]

100. Geary, R.S.; Norris, D.; Yu, R.; Bennett, C.F. Pharmacokinetics, biodistribution and cell uptake of antisense oligonucleotides. Adv. Drug Deliv. Rev. 2015, 87, 46-51. [CrossRef] [PubMed]

101. Lee, S. Regulation of muscle mass by myostatin. Annu. Rev. Cell Dev. Biol. 2004, 20, 61-86. [CrossRef] [PubMed]

102. Kemaladewi, D.U.; Pasteuning, S.; van Der Meulen, J.W.; van Heiningen, S.H.; van Ommen, G.; Ten Dijke, P.; Aartsma-Rus, A.; AC't Hoen, P.; Hoogaars, W.M. Targeting TGF- $\beta$ signaling by antisense oligonucleotide-mediated knockdown of TGF- $\beta$ type I receptor. Mol. Ther. Nucleic Acids 2014, 3. [CrossRef] [PubMed]

103. Kemaladewi, D.U.; Hoogaars, W.M.H.; van Heiningen, S.H.; Terlouw, S.; de Gorter, D.J.J.; den Dunnen, J.T.; van Ommen, G.J.; Aartsma-Rus, A.; ten Dijke, P.; AC't Hoen, P. Dual exon skipping in myostatin and dystrophin for Duchenne muscular dystrophy. BMC Med. Genom. 2011, 4, 36. [CrossRef] [PubMed]

104. Jin, S.; Kim, C.; Kim, Y. Cellular delivery of cationic lipid nanoparticle-based SMAD3 antisense oligonucleotides for the inhibition of collagen production in keloid fibroblasts. Eur. J. Pharm. Biopharm. 2012, 82, 19-26. [CrossRef] [PubMed]

105. Kim, J.; An, H.; Kim, W.; Gwon, M.; Gu, H.; Park, Y.; Park, K.K. Anti-fibrotic effects of synthetic oligodeoxynucleotide for TGF- $\beta 1$ and Smad in an animal model of liver cirrhosis. Mol. Ther. Nucleic Acids 2017, 8, 250-263. [CrossRef] [PubMed]

106. Thum, T.C.; Gross, J.; Fiedler, T.; Fischer, S.; Kissler, M.; Bussen, P.; Galuppo, P.; Just, S.; Rottbauer, W.; Frantz, S.; et al. MicroRNA-21 contributes to myocardial disease by stimulating MAP kinase signalling in fibroblasts. Nature 2008, 456, 980-984. [CrossRef] [PubMed]

107. Chau, B.N.; Xin, C.; Hartner, J.; Ren, S.; Castano, A.P.; Linn, G.; Li, J.; Tran, P.T.; Kaimal, V.; Huang, X.; et al. MicroRNA-21 promotes fibrosis of the kidney by silencing metabolic pathways. Sci. Transl. Med. 2012, 15, 121ra18. [CrossRef] [PubMed]

108. Montgomery, R.L.; Hullinger, T.G.; Semus, H.M.; Dickinson, B.A.; Seto, A.G.; Lynch, J.M.; Stack, C.; Latimer, P.A.; Olson, E.N.; van Rooij, E. Therapeutic inhibition of miR-208a improves cardiac function and survival during heart failure. Circulation 2011, 4, 1537-1547. [CrossRef] [PubMed]

109. Hullinger, T.G.; Montgomery, R.L.; Seto, A.G.; Dickinson, B.A.; Semus, H.M.; Lynch, J.M.; Dalby, C.M.; Robinson, K.; Stack, C.; Latimer, P.A.; et al. Inhibition of miR-15 protects against cardiac ischemic injury. Circ. Res. 2012, 110, 71-81. [CrossRef] [PubMed]

110. Boon, R.A.; Iekushi, K.; Lechner, S.; Seeger, T.; Fischer, A.; Heydt, S.; Kaluza, D.; Treguer, K.; Carmona, G.; Bonauer, A.; et al. MicroRNA-34a regulates cardiac ageing and function. Nature 2013, 495, 107-110. [CrossRef] [PubMed] 
111. Bernardo, B.C.; Gao, X.M.; Winbanks, C.E.; Boey, E.J.; Tham, Y.K.; Kiriazis, H.; Gregorevic, P.; Obad, S.; Kauppinen, S.; Du, X.J.; et al. Therapeutic inhibition of the miR-34 family attenuates pathological cardiac remodeling and improves heart function. Proc. Natl. Acad. Sci. USA 2012, 109, 17615-17620. [CrossRef] [PubMed]

112. Igarashi, A.; Okochi, H.; Bradham, D.M.; Grotendorst, G.R. Regulation of connective tissue growth factor gene expression in human skin fibroblasts and during wound repair. Mol. Biol. Cell 1993, 4, 637-645. [CrossRef] [PubMed]

113. Igarashi, A.; Nashiro, K.; Kikuchi, K.; Sato, S.; Ihn, H.; Gary, R.G.; Takehara, K. Significant correlation between connective tissue growth factor gene expression and skin sclerosis in tissue sections from patients with systemic sclerosis. J. Investig. Dermatol. 1995, 105, 280-284. [CrossRef] [PubMed]

114. Igarashi, A.; Nashiro, K.; Kikuchi, K.; Sato, S.; Ihn, H.; Fujimoto, M.; Gary, R.G.; Takehara, K. Connective tissue growth factor gene expression in tissue sections from localized scleroderma, keloid, and other fibrotic skin disorders. J. Investig. Dermatol. 1996, 106, 729-733. [CrossRef] [PubMed]

115. Paradis, V.; Dargere, D.; Vidaud, M.; De Gouville, A.; Huet, S.; Martinez, V.; Gauthier, J.; Ba, N.; Sobesky, R.; Ratziu, V.; et al. Expression of connective tissue growth factor in experimental rat and human liver fibrosis. Hepatology 1999, 30, 968-976. [CrossRef] [PubMed]

116. Ito, Y.; Aten, J.; Richard, J.B.; Barry, S.O.; Ton, J.R.; Jan, J.W.; Goldschmeding, R. Expression of connective tissue growth factor in human renal fibrosis. Kidney Int. 1998, 53, 853-861. [CrossRef] [PubMed]

117. Sun, G.; Haginoya, K.; Wu, Y.; Chiba, Y.; Nakanishi, T.; Onuma, A.; Sato, Y.; Takigawa, M.; Iinuma, K.; Tsuchiya, S. Connective tissue growth factor is overexpressed in muscles of human muscular dystrophy. J. Neurol. Sci. 2008, 267, 48-56. [CrossRef] [PubMed]

118. Adler, S.G.; Schwartz, S.; Williams, M.E.; Arauz-Pacheco, C.; Bolton, W.K.; Lee, T.; Li, D.; Neff, T.B.; Urquilla, P.R.; Sewell, K.L. Phase 1 study of anti-CTGF monoclonal antibody in patients with diabetes and microalbuminuria. Clin. J. Am. Soc. Nephrol. 2010, 5, 1420-1428. [CrossRef] [PubMed]

119. Wang, Q.; Usinger, W.; Nichols, B.; Gray, J.; Xu, L.; Seeley, T.W.; Brenner, M.; Guo, G.; Zhang, W.; Oliver, N.; et al. Cooperative interaction of CTGF and TGF-beta in animal models of fibrotic disease. Fibrogenes. Tissue Repair 2011, 4, 4. [CrossRef] [PubMed]

120. Morales, M.G.; Gutierrez, J.; Cabello-Verrugio, C.; Cabrera, D.; Lipson, K.; Goldschmeding, R.; Brandan, E. Reducing CTGF/CCN2 slows down mdx muscle dystrophy and improves cell therapy. Hum. Mol. Genet. 2013, 22, 4938-4951. [CrossRef] [PubMed]

121. Raghu, G.; Scholand, M.B.; de Andrade, J.; Lancaster, L.; Mageto, Y.; Goldin, J.; Brown, K.K.; Flaherty, K.R.; Wencel, M.; Wanger, J.; et al. FG-3019 anti-connective tissue growth factor monoclonal antibody: Results of an open-label clinical trial in idiopathic pulmonary fibrosis. Eur. Respir. J. 2016, 47, 1481-1491. [CrossRef] [PubMed]

122. Xiao, R.; Liu, F.; Luo, J.; Yang, X.; Wen, H.; Su, Y.; Yan, K.; Li, Y.; Liang, Y. Effect of small interfering RNA on the expression of connective tissue growth factor and type I and III collagen in skin fibroblasts of patients with systemic sclerosis. Br. J. Dermatol. 2006, 155, 1145-1453. [CrossRef] [PubMed]

123. Li, G.; Xie, Q.; Shi, Y.; Li, D.; Zhang, M.; Jiang, S.; Zhou, H.; Lu, H.; Jin, Y. Inhibition of connective tissue growth factor by siRNA prevents liver fibrosis in rats. J. Gene Med. 2006, 8, 889-900. [CrossRef] [PubMed]

124. Hao, C.; Xie, Y.; Peng, M.; Ma, L.; Zhou, Y.; Zhang, Y.; Kang, W.; Wang, J.; Bai, X.; Wang, P.; et al. Inhibition of connective tissue growth factor suppresses hepatic stellate cell activation in vitro and prevents liver fibrosis in vivo. Clin. Exp. Med. 2014, 14, 141-150. [CrossRef] [PubMed]

125. Yokoi, H.; Sugawara, A.; Mukoyama, M.; Mori, K.; Makino, H.; Suganami, T.; Nagae, T.; Yahata, K.; Fujinaga, Y.; Tanaka, I.; et al. Role of connective tissue growth factor in profibrotic action of transforming growth factor- $\beta$ : A potential target for preventing renal fibrosis. Am. J. Kidney Dis. 2001, 38, S134-S138. [CrossRef] [PubMed]

126. Yokoi, H.; Mukoyama, M.; Sugawara, A.; Mori, K.; Nagae, T.; Makino, H.; Suganami, T.; Yahata, K.; Fujinaga, Y.; Tanaka, I.; et al. Role of connective tissue growth factor in fibronectin expression and tubulointerstitial fibrosis. Am. J. Physiol. Renal. Physiol. 2002, 282, F933-F942. [CrossRef] [PubMed]

127. Yokoi, H.; Mukoyama, M.; Nagae, T.; Mori, K.; Suganami, T.; Sawai, K.; Yoshioka, T.; Koshikawa, M.; Nishida, T.; Takigawa, M.; et al. Reduction in connective tissue growth factor by antisense treatment ameliorates renal tubulointerstitial fibrosis. J. Am. Soc. Nephrol. 2004, 15, 14301440. [CrossRef] 
128. Guha, M.; Xu, Z.; Tung, D.; Lanting, L.; Natarajan, R. Specific down-regulation of connective tissue growth factor attenuates progression of nephropathy in mouse models of type 1 and type 2 diabetes. FASEB J. 2007, 21, 3355-3368. [CrossRef] [PubMed]

129. Sisco, M.; Kryger, Z.B.; O’Shaughnessy, K.D.; Kim, P.S.; Schultz, G.S.; Ding, X.; Roy, N.K.; Dean, N.M.; Mustoe, T.A. Antisense inhibition of connective tissue growth factor (CTGF/CCN2) mRNA limits hypertrophic scarring without affecting wound healing in vivo. Wound Repair Regen. 2008, 16, 661-673. [CrossRef] [PubMed]

130. Takeshita, S.; Kikuno, R.; Tezuka, K.; Amann, E. Osteoblast-specific factor 2: Cloning of a putative bone adhesion protein with homology with the insect protein fasciclin I. Biochem. J. 1993, 294, 271-278. [CrossRef] [PubMed]

131. Horiuchi, K.; Amizuka, N.; Takeshita, S.; Takamatsu, H.; Katsuura, M.; Ozawa, H.; Toyama, Y.; Bonewald, L.F.; Kudo, A. Identification and Characterization of a Novel Protein, Periostin, with Restricted Expression to Periosteum and Periodontal Ligament and Increased Expression by Transforming Growth Factor $\beta$. J. Bone Miner. Res. 1999, 14, 1239-1249. [CrossRef] [PubMed]

132. Bornstein, P.; Sage, E.H. Matricellular proteins: Extracellular modulators of cell function. Curr. Opin. Cell Biol. 2002, 14, 608-616. [CrossRef]

133. Hamilton, D. Functional role of periostin in development and wound repair: Implications for connective tissue disease. J. Cell Commun. Signal. 2008, 2, 9-17. [CrossRef] [PubMed]

134. Hoersch, S.; Andrade-Navarro, M.A. Periostin shows increased evolutionary plasticity in its alternatively spliced region. BMC Evol. Biol. 2010, 10, 30. [CrossRef] [PubMed]

135. Goetsch, S.C.; Hawke, T.J.; Gallardo, T.D.; Richardson, J.A.; Garry, D.J. Transcriptional profiling and regulation of the extracellular matrix during muscle regeneration. Physiol. Genom. 2003, 14, 261-271. [CrossRef] [PubMed]

136. Jackson-Boeters, L.; Wen, W.; Hamilton, D. Periostin localizes to cells in normal skin, but is associated with the extracellular matrix during wound repair. J. Cell Commun. Signal. 2009, 3, 125-133. [CrossRef] [PubMed]

137. Özdemir, C.; Akpulat, U.; Sharafi, P.; Yıldız, Y.; Onbaşılar, I.; Kocaefe, Ç. Periostin is temporally expressed as an extracellular matrix component in skeletal muscle regeneration and differentiation. Gene 2014, 553, 130-139. [CrossRef] [PubMed]

138. Stanton, L.W.; Garrard, L.J.; Damm, D.; Garrick, B.L.; Lam, A.; Kapoun, A.M.; Zheng, Q.; Protter, A.A.; Schreiner, G.F.; White, R.T. Altered patterns of gene expression in response to myocardial infarction. Circ. Res. 2000, 86, 939-945. [CrossRef] [PubMed]

139. Oka, T.; Xu, J.; Kaiser, R.A.; Melendez, J.; Hambleton, M.; Sargent, M.A.; Lorts, A.; Brunskill, E.W.; Dorn, G.W.; Conway, S.J.; et al. Genetic manipulation of periostin expression reveals a role in cardiac hypertrophy and ventricular remodeling. Circ. Res. 2007, 101, 313-321. [CrossRef] [PubMed]

140. Shimazaki, M.; Nakamura, K.; Kii, I.; Kashima, T.; Amizuka, N.; Li, M.; Saito, M.; Fukuda, K.; Nishiyama, T.; Kitajima, S.; et al. Periostin is essential for cardiac healing after acute myocardial infarction. J. Exp. Med. 2008, 205, 295-303. [CrossRef] [PubMed]

141. Zhao, S.; Wu, H.; Xia, W.; Chen, X.; Zhu, S.; Zhang, S.; Shao, Y.; Ma, W.; Yang, D.; Zhang, J. Periostin expression is upregulated and associated with myocardial fibrosis in human failing hearts. J. Cardiol. 2014, 63, 373-378. [CrossRef] [PubMed]

142. Takayama, G.; Arima, K.; Kanaji, T.; Toda, S.; Tanaka, H.; Shoji, S.; Mckenzie, A.N.J.; Nagai, H.; Hotokebuchi, T.; Izuhara, K. Periostin: A novel component of subepithelial fibrosis of bronchial asthma downstream of IL-4 and IL-13 signals. J. Allergy Clin. Immunol. 2006, 118, 98-104. [CrossRef] [PubMed]

143. Sidhu, S.S.; Yuan, S.; Innes, A.L.; Kerr, S.; Woodruff, P.G.; Hou, L.; Muller, S.J.; Fahy, J.V. Roles of epithelial cell- derived periostin in TGF-beta activation, collagen production, and collagen gel elasticity in asthma. Proc. Natl. Acad. Sci. USA 2010, 107, 14170-14175. [CrossRef] [PubMed]

144. Norris, R.A.; Damon, B.; Mironov, V.; Kasyanov, V.; Ramamurthi, A.; Moreno-Rodriguez, R.; Trusk, T.; Potts, J.D.; Goodwin, R.L.; Davis, J.; et al. Periostin regulates collagen fibrillogenesis and the biomechanical properties of connective tissues. J. Cell. Biochem. 2007, 101, 695-711. [CrossRef] [PubMed]

145. Kii, I.; Nishiyama, T.; Li, M.; Matsumoto, K.; Saito, M.; Amizuka, N.; Kudo, A. Incorporation of tenascin-C into the extracellular matrix by periostin underlies an extracellular meshwork architecture. J. Biol. Chem. 2010, 285, 2028-2039. [CrossRef] [PubMed] 
146. Maruhashi, T.; Kii, I.; Saito, M.; Kudo, A. Interaction between periostin and BMP-1 promotes proteolytic activation of lysyl oxidase. J. Biol. Chem. 2010, 285, 13294-13303. [CrossRef] [PubMed]

147. Gillan, L.; Matei, D.; Fishman, D.A.; Gerbin, C.S.; Karlan, B.Y.; Chang, D.D. Periostin secreted by epithelial ovarian carcinoma is a ligand for alpha(V)beta(3) and alpha(V)beta(5) integrins and promotes cell motility. Cancer Res. 2002, 62, 5358-5364. [PubMed]

148. Bao, S.; Ouyang, G.; Bai, X.; Huang, Z.; Ma, C.; Liu, M.; Shao, R.; Anderson, R.M.; Rich, J.N.; Wang, X. Periostin potently promotes metastatic growth of colon cancer by augmenting cell survival via the Akt/PKB pathway. Cancer Cell 2004, 5, 329-339. [CrossRef]

149. Baril, P.; Gangeswaran, R.; Mahon, P.C.; Caulee, K.; Kocher, H.M.; Harada, T.; Zhu, M.; Kalthoff, H.; Crnogorac-Jurcevic, T.; Lemoine, N.R. Periostin promotes invasiveness and resistance of pancreatic cancer cells to hypoxia-induced cell death: Role of the $\beta 4$ integrin and the PI3k pathway. Oncogene 2007, 26, 2082-2094. [CrossRef] [PubMed]

150. Butcher, J.T.; Norris, R.A.; Hoffman, S.; Mjaatvedt, C.H.; Markwald, R.R. Periostin promotes atrioventricular mesenchyme matrix invasion and remodeling mediated by integrin signaling through Rho/PI3-kinase. Dev. Biol. 2007, 302, 256-266. [CrossRef] [PubMed]

151. Um, J.; Park, J.; Nam, B.; Lee, J.; Jung, J.; Kim, Y.; Kim, S.; Park, J.; Wu, M.; Han, S.; et al. Periostin-binding DNA aptamer treatment attenuates renal fibrosis under diabetic conditions. Sci. Rep. 2017, 7, 8490. [CrossRef] [PubMed]

152. Takai, S.; Yoshino, M.; Takao, K.; Yoshikawa, K.; Jin, D. Periostin antisense oligonucleotide prevents adhesion formation after surgery in mice. J. Pharmacol. Sci. 2017, 133, 65-69. [CrossRef] [PubMed]

153. Semba, T.; Sugihara, E.; Kamoshita, N.; Ueno, S.; Fukuda, K.; Yoshino, M.; Takao, K.; Yoshikawa, K.; Izuhara, K.; Arima, Y.; et al. Periostin antisense oligonucleotide suppresses bleomycin-induced formation of a lung premetastatic niche for melanoma. Cancer Sci. 2018, 109. [CrossRef] [PubMed]

154. Ratajczak-Wielgomas, K.; Dziegiel, P. The role of periostin in neoplastic processes. Folia Histochem. Cytobiol. 2015, 53, 120-132. [CrossRef] [PubMed]

155. Lister, N.C.; Clemson, M.; Morris, K.V. RNA-directed epigenetic silencing of periostin inhibits cell motility. R. Soc. Open Sci. 2015, 2, 140545. [CrossRef] [PubMed]

156. Lagente, V.; Manoury, B.; Nenan, S.; Le Quement, C.; Martin-Chouly, C.; Boichot, E. Role of matrix metalloproteinases in the development of airway inflammation and remodeling. Braz. J. Med. Biol. Res. 2005, 38, 1521-1530. [CrossRef] [PubMed]

157. Alameddine, H.S.; Morgan, J.E. Matrix metalloproteinases and tissue inhibitor of metalloproteinases in inflammation and fibrosis of skeletal muscles. J. Neuromuscul. Dis. 2016, 29, 455-473. [CrossRef] [PubMed]

158. Bernardo, M.M.; Fridman, R. TIMP-2 (tissue inhibitor of metalloproteinase-2) regulates MMP-2 (matrix metalloproteinase-2) activity in the extracellular environment after pro-MMP-2 activation by MT1 (membrane type 1)-MMP. Biochem. J. 2003, 374, 739-745. [CrossRef] [PubMed]

159. Kim, Y.; Remacle, A.G.; Chernov, A.V.; Liu, H.; Shubayev, I.; Lai, C.; Dolkas, J.; Shiryaev, S.A.; Golubkov, V.S.; Mizisin, A.P.; et al. The MMP-9/TIMP-1 axis controls the status of differentiation and function of myelin-forming Schwann cells in nerve regeneration. PLoS ONE 2012, 7, e33664. [CrossRef] [PubMed]

160. Tang, H.; Mao, J.; Gao, L.; Liu, J.; Wu, T. Effect of antisense TIMP-1 cDNA on the expression of TIMP-1 and MMP-2 in lung tissue with pulmonary fibrosis induced by bleomycin. Mol. Med. Rep. 2013, 7, 149-153. [CrossRef] [PubMed]

161. Nie, Q.H.; Cheng, Y.Q.; Xie, Y.M.; Zhou, Y.X.; Cao, Y.Z. Inhibiting effect of antisense oligonucleotides phosphorthioate on gene expression of TIMP-1 in rat liver fibrosis. World J. Gastroenterol. 2001, 7, 363-369. [CrossRef] [PubMed]

162. Nie, Q.H.; Zhu, C.L.; Zhang, Y.F.; Yang, J.; Zhang, J.C.; Gao, R.T. Inhibitory effect of antisense oligonucleotide targeting TIMP-2 on immune-induced liver fibrosis. Dig. Dis. Sci. 2010, 55, 1286-1295. [CrossRef] [PubMed]

163. Chen, Z.; Tan, W.; Zhang, L.; Tan, Q.; Yang, J. Beneficial impact of bFGF antisense therapy in a rat model of pulmonary fibrosis. Sarcoidosis Vasc. Diffuse Lung Dis. 2015, 32, 22-31. [PubMed]

164. Wang, J.H.; Newbury, L.J.; Knisely, A.S.; Monia, B.; Hendry, B.M.; Sharpe, C.C. Antisense knockdown of Kras inhibits fibrosis in a rat model of unilateral ureteric obstruction. Am. J. Pathol. 2012, 180, 82-90. [CrossRef] [PubMed] 
165. Verrecchia, F.; Rossert, J.; Mauviel, A. Blocking sp1 transcription factor broadly inhibits extracellular matrix gene expression in vitro and in vivo: Implications for the treatment of tissue fibrosis. J. Investig. Dermatol. 2001, 116, 755-763. [CrossRef] [PubMed]

166. Zhou, Y.; Chen, Y.; Zhang, X.; Tan, M.; Zheng, R.; Zhao, L. Intervention of transforming pulmonary fibrosis with NF-kB p65 antisense oligonucleotide. Int. J. Clin. Exp. Med. 2014, 7, 5252-5259. [PubMed]

167. Lawrance, I.C.; Wu, F.; Leite, A.Z.; Willis, J.; West, G.A.; Fiocchi, C.; Chakravarti, S. A murine model of chronic inflammation-induced intestinal fibrosis down-regulated by antisense NF-kB. Gastroenterology 2003, 125, 1750-1761. [CrossRef] [PubMed]

168. Fan, X.M.; Wang, Z.L.; Li, Z.H. STAT1 activation and STAT1-dependent immune-response gene ICAM-1 expression in alveolar macrophages of rats suffered from interstitial pulmonary fibrosis. Xi Bao Yu Fen Zi Mian Yi Xue Za Zhi 2003, 19, 3-6. [PubMed]

169. Wettstein, G.; Bellaye, P.S.; Kolb, M.; Hammann, A.; Crestani, B.; Soler, P.; Marchal-Somme, J.; Hazoume, A.; Gauldie, J.; Gunther, A.; et al. Inhibition of HSP27 blocks fibrosis development and EMT features by promoting Snail degradation. FASEB J. 2013, 27, 1549-1560. [CrossRef] [PubMed]

170. Campbell, C.; McMillan, H.J.; Mah, J.K.; Tarnopolsky, M.; Selby, K.; McClure, T.; Wilson, D.M.; Sherman, M.L.; Escolar, D.; Attie, K.M. Myostatin inhibitor ACE-031 treatment of ambulatory boys with Duchenne muscular dystrophy: Results of a randomized, placebo-controlled clinical trial. Muscle Nerve 2017, 55, 458-464. [CrossRef] [PubMed]

171. Wahl, S.M. Transforming growth factor beta: The good, the bad, and the ugly. J. Exp. Med. 1994, 180, 1587-1590. [CrossRef] [PubMed]

172. Shull, M.M.; Ormsby, I.; Kier, A.B.; Pawlowski, S.; Diebold, R.J.; Yin, M.; Allen, R.; Sidman, C.; Proetzel, G.; Calvin, D.; et al. Targeted disruption of the mouse transforming growth factor- $\beta 1$ gene results in multifocal inflammatory disease. Nature 1992, 359, 693-699. [CrossRef] [PubMed]

173. Ferguson, D.P.; Dangott, L.J.; Lightfoot, J.T. Lessons learned from vivo-morpholinos: How to avoid vivo-morpholino toxicity. BioTechniques 2014, 56, 251-256. [CrossRef] [PubMed]

174. Godfrey, C.; Desviat, L.R.; Smedsrød, B.; Piétri-Rouxel, F.; Denti, M.A.; Disterer, P.; Lorain, S.; Nogales-Gadea, G.; Sardone, V.; Anwar, R.; et al. Delivery is key: Lessons learnt from developing splice-switching antisense therapies. EMBO Mol. Med. 2017, 9, 545-557. [CrossRef] [PubMed]

175. Juliano, R.L. The delivery of therapeutic oligonucleotides. Nucleic Acids Res. 2016, 44, 6518-6548. [CrossRef] [PubMed]

176. Yin, H.; Moulton, H.M.; Seow, Y.; Boyd, C.; Boutilier, J.; Iverson, P.; Wood, M.J.A. Cell-penetrating peptide-conjugated antisense oligonucleotides restore systemic muscle and cardiac dystrophin expression and function. Hum. Mol. Genet. 2008, 7, 3909-3918. [CrossRef] [PubMed]

177. Koren, E.; Torchilin, V.P. Cell-penetrating peptides: Breaking through to the other side. Trends Mol. Med. 2012, 18, 385-393. [CrossRef] [PubMed]

178. Lehto, T.; Castillo Alvarez, A.; Gauck, S.; Gait, M.J.; Coursindel, T.; Wood, M.J.A.; Lebleu, B.; Boisguerin, P. Cellular trafficking determines the exon skipping activity of Pip6a-PMO in mdx skeletal and cardiac muscle cells. Nucleic Acids Res. 2014, 42, 3207-3217. [CrossRef] [PubMed]

179. Ezzat, K.; Aoki, Y.; Koo, T.; Mcclorey, G.; Benner, L.; Coenen-Stass, A.; O’Donovan, L.; Lehto, T.; Garcia-Guerra, A.; Nordin, J.; et al. Self-assembly into nanoparticles is essential for receptor mediated uptake of therapeutic antisense oligonucleotides. Nano Lett. 2015, 15, 4364-4373. [CrossRef] [PubMed]

(C) 2018 by the authors. Licensee MDPI, Basel, Switzerland. This article is an open access article distributed under the terms and conditions of the Creative Commons Attribution (CC BY) license (http://creativecommons.org/licenses/by/4.0/). 